Article

\title{
Composite Membranes of Poly( $\varepsilon$-caprolactone) with Bisphosphonate-Loaded Bioactive Glasses for Potential Bone Tissue Engineering Applications
}

\author{
Zoi Terzopoulou ${ }^{1, *(1)}$, Diana Baciu ${ }^{2}$, Eleni Gounari ${ }^{3}{ }^{(\mathbb{D}}$, Theodore Steriotis ${ }^{2}{ }^{(D)}$, \\ Georgia Charalambopoulou ${ }^{2}\left(\mathbb{D}\right.$, Dimitrios Tzetzis ${ }^{4}\left(\mathbb{D}\right.$ and Dimitrios Bikiaris ${ }^{1}(\mathbb{D})$ \\ 1 Laboratory of Polymer Chemistry and Technology, Department of Chemistry, \\ Aristotle University of Thessaloniki, GR54124 Thessaloniki, Central Macedonia, Greece \\ 2 National Center for Scientific Research "Demokritos", GR15341 Athens, Ag. Paraskevi Attikis, Greece \\ 3 Biohellenika Biotechnology Company, Leoforos Georgikis Scholis 65, GR57001 Thessaloniki, \\ Central Macedonia, Greece \\ 4 School of Science and Technology, International Hellenic University, GR57001 Thermi, \\ Central Macedonia, Greece \\ * Correspondence: terzozoi@chem.auth.gr; Tel.: +30-69-7567-1876
}

Academic Editors: Dimitrios Bikiaris and Dimitrios G. Papageorgiou

Received: 19 July 2019; Accepted: 21 August 2019; Published: 23 August 2019

check for updates

\begin{abstract}
Poly( $\varepsilon$-caprolactone) (PCL) is a bioresorbable synthetic polyester with numerous biomedical applications. PCL membranes show great potential in guided tissue regeneration because they are biocompatible, occlusive and space maintaining, but lack osteoconductivity. Therefore, two different types of mesoporous bioactive glasses $\left(\mathrm{SiO}_{2}-\mathrm{CaO}-\mathrm{P}_{2} \mathrm{O}_{5}\right.$ and $\left.\mathrm{SiO}_{2}-\mathrm{SrO}-\mathrm{P}_{2} \mathrm{O}_{5}\right)$ were synthesized and incorporated in PCL thin membranes by spin coating. To enhance the osteogenic effect of resulting membranes, the bioglasses were loaded with the bisphosphonate drug ibandronate prior to their incorporation in the polymeric matrix. The effect of the composition of the bioglasses as well as the presence of absorbed ibandronate on the physicochemical, cell attachment and differentiation properties of the PCL membranes was evaluated. Both fillers led to a decrease of the crystallinity of PCL, along with an increase in its hydrophilicity and a noticeable increase in its bioactivity. Bioactivity was further increased in the presence of a Sr substituted bioglass loaded with ibandronate. The membranes exhibited excellent biocompatibility upon estimation of their cytotoxicity on Wharton's Jelly Mesenchymal Stromal Cells (WJ-SCs), while they presented higher osteogenic potential in comparison with neat PCL after WJ-SCs induced differentiation towards bone cells, which was enhanced by a possible synergistic effect of $\mathrm{Sr}$ and ibandronate.
\end{abstract}

Keywords: bioactive glasses; poly ( $\varepsilon$-caprolactone); nanocomposites; strontium; ion release; biocompatibility; osteogenesis; bone tissue engineering

\section{Introduction}

Guided tissue/bone regeneration (GTR/GBR) with barrier membranes is a commonly used approach for enhanced bone regeneration, especially during periodontal defect healing [1]. These membranes act as an occlusive barrier that blocks cell migration from connective tissue and epithelium to the defect, which can interfere with tissue regeneration and consequently provides the tissue with adequate time to heal [2,3]. Ideally, a GTR/GBR membrane is biocompatible, non-immunogenic, non-toxic, biodegradable after mechanically supporting tissue formation and able to stimulate cellular exclusion at the affected location and maintain a space for the surrounding healthy tissue to migrate $[4,5]$.

Commercially available GTR/GBR membranes are either non-resorbable (polytetrafluoro-ethylene), or resorbable (polylactide (PLA), polylactide-co-glycolide (PLGA), polylactide-co-caprolactone, 
collagen) [5]. While non-resorbable membranes show excellent biocompatibility, they do require an additional surgical procedure for their removal and may cause soft tissue dehiscence [6]. These complications resulted in the commercialization of resorbable membranes that are however still constructed of bioinert polymers that lack osteoconductive/osteoinductive properties. Poly( $\varepsilon$-caprolactone) (PCL) has attracted a lot of attention due to its excellent biocompatibility, good biodegradability, easy handling, sterilization capability, inexpensive manufacturing process and control over the biodegradation rate, which resulted in its FDA approval for several clinical uses [7]. Compared with the most commonly used PLA and PLGA, PCL doesn't release acidic degradation products that could affect cell growth [4]. Although PCL has many advantages, only a handful of studies have been published concerning PCL based membranes for GTR/GBR [8-15], as it shows low bioactivity, high hydrophobicity and weak mechanical properties that limit its effectiveness $[15,16]$.

A commonly used method to increase bioactivity, alter the degradation rate, improve mechanical properties and enhance cell adhesion and proliferation on polymeric surfaces intended for tissue engineering applications including GTR/GBR [11,15,17-30], is the incorporation of bioactive inorganic fillers, like hydroxyapatite, tricalcium phosphate or bioglasses (BGs) [31-37]. BGs consist of a silicon dioxide-based network modified by other metal oxides such as $\mathrm{Na}_{2} \mathrm{O}, \mathrm{CaO}$ and $\mathrm{P}_{2} \mathrm{O}_{5}$ [38]. They are among the most used synthetic materials in bone tissue engineering applications due to their excellent biocompatibility as well as their ability to stimulate osteogenesis and angiogenesis [39,40]. Several inorganic ions are shown to stimulate bone formation, with $\mathrm{Ca}$ and $\mathrm{P}$ being essential for bone mineralization as they comprise the main elements of hydroxyapatite [HA, $\left.\mathrm{Ca}_{10}\left(\mathrm{PO}_{4}\right)_{6}(\mathrm{OH})_{2}\right]$ [41]. Recently, the impact of other ions including $\mathrm{Si}, \mathrm{Zn}, \mathrm{Mg}$, $\mathrm{Sr}, \mathrm{Ti}, \mathrm{B}$ and $\mathrm{Cu}$ on bone formation has been reported [42], that led to an increasing number of studies on BGs with different substitutions [43]. Among them, Sr shows beneficial effects on bone cells and for bone formation in vivo and for osteogenic differentiation at low doses [44-51]. Another approach to provide occlusive GTR membranes with the ability to regenerate bone is the incorporation of growth factors, drugs or other biomolecules $[5,52,53]$. However, the physical adsorption of biomolecules on polymeric membranes has the drawbacks of low immobilization efficiency and fast desorption which make their covalent bonding on the polymer necessary [53]. To overcome these problems, BGs can be used as both fillers and drug carriers in order to provide the membranes with bioactivity and hydrophilicity and additionally act as vehicles for the encapsulation of a drug molecule $[18,54,55]$. The adsorption of the drug or other biomolecules which can usually be quite unstable can both protect these molecules and control their release rate. Furthermore, since osteoconductive drugs and biomolecules are predominantly hydrophilic, their addition in hydrophobic polymeric films like PCL would be unsuccessful.

The combination of bisphosphonate (BP) drugs like alendronate and clodronate with bioglass, results in hybrid particles with a stronger capacity to regenerate bone defects than bioglass on its own $[56,57]$. It was also hypothesized that $\mathrm{Sr}$ substituted bioglass would further boost the osteogenic potential of BP-BG hybrid particles [56]. Potent osteoinductive drugs like BPs are used for treating various skeletal disorders, like osteoporosis, tumor-associated osteolysis, hypercalcemia and Paget's disease [58-60]. BPs enhance osteoblast proliferation and maturation, inhibit osteoblast apoptosis and increase bone formation [61]. The clinical pharmacology of BPs revealed that their affinity to hydroxyapatite is the basis for their use as inhibitors of ectopic calcification and bone resorption [59]. Since their bioavailability when administered orally is very low $(1-6 \%)$, localized delivery has been studied and it was reported that local delivery of BPs can lead to an improvement in bone growth around implants [62].

In our previous work, we demonstrated that the incorporation of $0.5,1$ and $2.5 \mathrm{wt} \%$ of nanosized mesoporous BGs in a PCL matrix via the in-situ ring opening polymerization of $\varepsilon$-caprolactone, resulted in a biocompatible PCL composite material with superior mechanical properties, accelerated biodegradation rate and bioactivity [63]. In this context, PCL/BG composites and nanocomposites are promising materials for a wide range of applications such as coatings for metallic or ceramic scaffolds 
for bone regeneration [64-66], as a solution for their high corrosion rates or low bioactivity, as root canal filling materials, or as bone scaffolds [15,63,67-70].

The aim of the present work was the development of BP-loaded composite thin PCL membranes with two mesoporous BGs of different compositions with improved characteristics for potential use as GTR/GBR membranes. The novel combination of the exceptional bioactivity of BGs with the capacity of BPs to strongly coordinate $\mathrm{Ca}^{2+}$ ions is expected to transform PCL to a highly bioactive and biocompatible membrane, suitable for GBR. Two types of mesoporous ternary BGs $\left(\mathrm{SiO}_{2}-\mathrm{CaO}-\mathrm{P}_{2} \mathrm{O}_{5}\right.$ and $\mathrm{SiO}_{2}-\mathrm{SrO}-\mathrm{P}_{2} \mathrm{O}_{5}$ ) were synthesized with a hydrothermal method aiming to investigate the effects of fully replacing Ca with Sr. Afterwards, the BP drug ibandronate (Iba) was loaded on the BGs. These BG fillers were finally incorporated at a concentration of $10 \mathrm{wt} \%$ in PCL films by spin coating. The obtained thin films were studied in terms of morphology, dispersion, thermal properties, mechanical properties, ion release, hydrophilicity, cell viability and the combined effect of the ions $\mathrm{Ca}, \mathrm{P}, \mathrm{Sr}$ and Iba on the bioactivity and osteogenic differentiation potential of the PCL membranes was evaluated.

\section{Results and Discussion}

\subsection{Characterization of the Bioglasses}

$\mathrm{SrO} / \mathrm{CaO}$ substitution has emerged as a new method in designing new bioactive materials for bone repair and regeneration [45]. Sr and $\mathrm{Ca}$ are similar in chemical nature in terms of ionic radius and charge, and the substitution of Ca with Sr does not considerably alter the basic chemical and physical properties of Ca-containing BGs and ceramics such as Bioglass ${ }^{\circledR}$, hydroxyapatite, and calcium phosphates. Sr however has a lower charge to size ratio that results in the formation of a looser glass network [44].

SEM images of the as-produced CaBG and SrBG BGs (Figure 1) show that the hydrothermal method employed and the calcination at $600{ }^{\circ} \mathrm{C}$ leads to the formation of aggregates of nanoparticles in both cases. DLS results (Table S1) report sizes of $235.7 \pm 26.11 \mathrm{~nm}$ for CaBG and $408.3 \pm 71.28 \mathrm{~nm}$ for SrBG. Their wide particle size could be attributed to the agglomeration of smaller nanoparticles during the crystal growth process [71]. According to the literature [72], increase of the CaO content in mesoporous bioglass nanoparticles results in decreased particle size. In contrast, increase of $\mathrm{Sr}^{2+}$ content was found to lead to a significant increase of the average particle size due to aggregation and coalescence of clusters [73]. The EDX elemental analysis (Table 1) confirmed the presence of $\mathrm{O}, \mathrm{Si}, \mathrm{P}$ and $\mathrm{Ca}$ in $\mathrm{CaBG}$ and $\mathrm{O}, \mathrm{Si}, \mathrm{P}$ and $\mathrm{Sr}$ in SrBG.

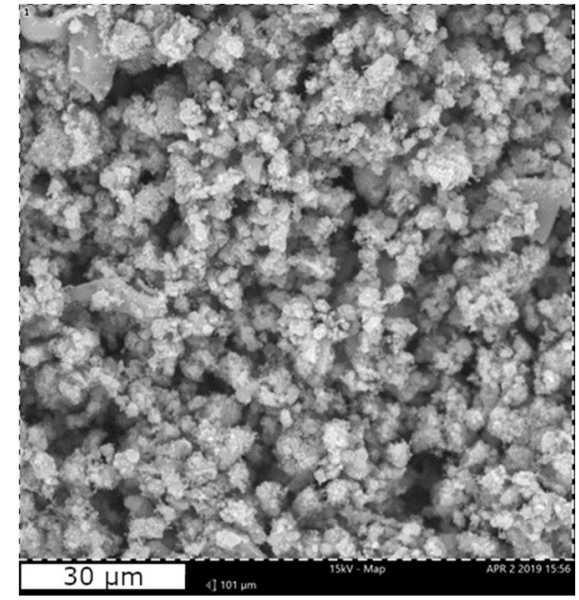

(a)

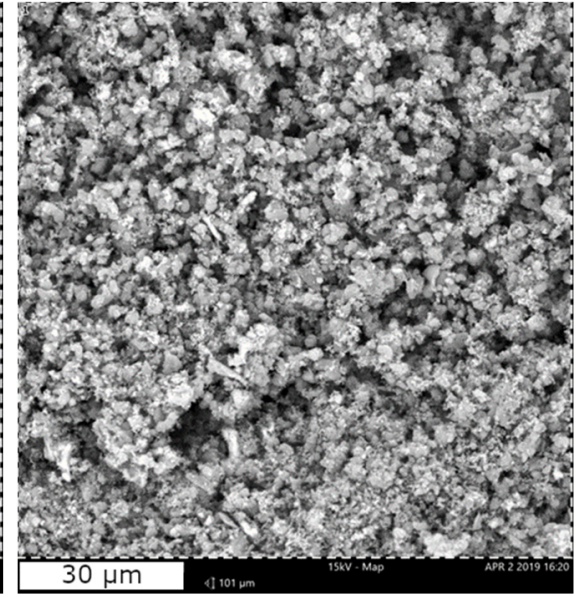

(b)

Figure 1. SEM micrographs of (a) CaBG and (b) SrBG bioglass particles. 
Table 1. EDX elemental analysis of CaBG and SrBG (\% atomic and weight concentrations, $n=3)$.

\begin{tabular}{ccccc}
\hline & \multicolumn{2}{c}{ CaBG } & \multicolumn{2}{c}{ SrBG } \\
\hline Element & Atomic conc. (\%) & Weight conc. (\%) & Atomic conc. (\%) & Weight conc. (\%) \\
\hline $\mathrm{O}$ & $64.39 \pm 2.87$ & $49.58 \pm 2.98$ & $57.89 \pm 2.01$ & $38.59 \pm 2.10$ \\
$\mathrm{Si}$ & $31.39 \pm 2.75$ & $42.33 \pm 3.03$ & $37.06 \pm 1.65$ & $43.30 \pm 1.11$ \\
$\mathrm{P}$ & $0.10 \pm 0.06$ & $0.14 \pm 0.09$ & $0.13 \pm 0.02$ & $0.17 \pm 0.04$ \\
$\mathrm{Ca}$ & $4.13 \pm 0.19$ & $7.94 \pm 0.30$ & 0 & 0 \\
$\mathrm{Sr}$ & 0 & 0 & $4.92 \pm 0.38$ & $17.94 \pm 1.06$ \\
\hline
\end{tabular}

FTIR spectra of both BGs are presented in Figure 2. Both samples exhibit mainly the stretching and bending vibrations of the $\mathrm{Si}-\mathrm{O}-\mathrm{Si}$ bridge. Characteristic bands between 400 and $500 \mathrm{~cm}^{-1}$ are assigned to the bending vibrations of the $\mathrm{Si}-\mathrm{O}-\mathrm{Si}$ and $\mathrm{O}-\mathrm{Si}-\mathrm{O}$ bonds $[74,75]$. The peak in the range of $760-810 \mathrm{~cm}^{-1}$ corresponds to the stretching vibrations of the $\mathrm{O}-\mathrm{Si}-\mathrm{O}$ bonds, while the peak in the range of $1000-1100 \mathrm{~cm}^{-1}$ is attributed to the symmetric stretching vibration of the $\mathrm{Si}-\mathrm{O}-\mathrm{Si}$ bonds [74]. The absorption peak at $1635 \mathrm{~cm}^{-1}$ is associated with the stretching mode of the $\mathrm{OH}$ group [75]. In addition, a weak band at cc. $570 \mathrm{~cm}^{-1}$ can be attributed to the asymmetric vibration of $\mathrm{PO}_{4}{ }^{3-}$ [76] . The FTIR spectrum of SrBG exhibits two additional peaks around $1478 \mathrm{~cm}^{-1}$ and $857 \mathrm{~cm}^{-1}$ that can be attributed to $\mathrm{C}-\mathrm{O}$ stretching in carbonate groups $\left(\mathrm{CO}_{3}{ }^{2-}\right)$, which can be formed by the reaction of SrBG with atmospheric $\mathrm{CO}_{2}[75,77,78]$. No peaks that can be assigned to organic matter are observed, confirming the purity of the materials.

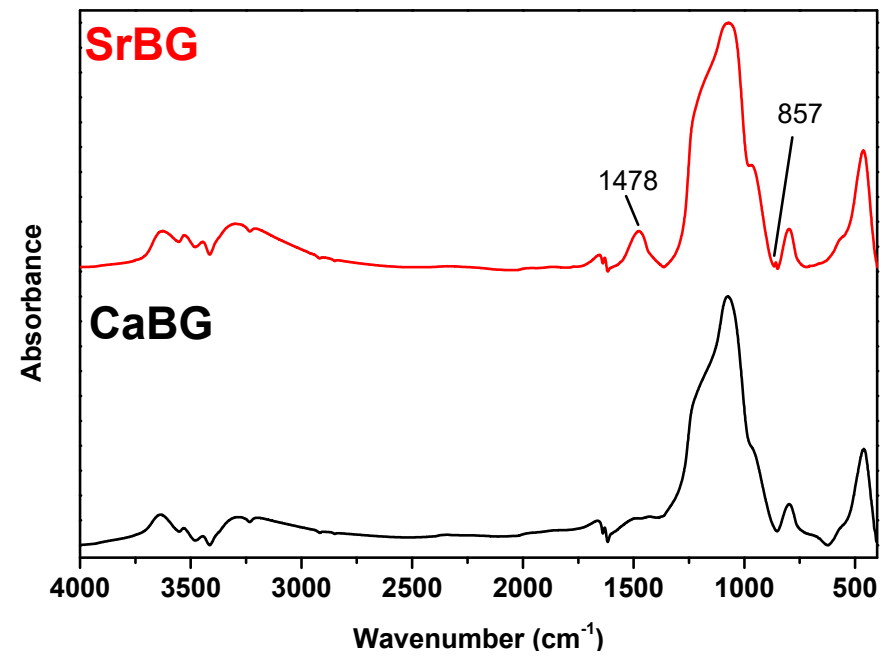

Figure 2. FTIR spectra of CaBG and SrBG BGs.

The wide-angle XRD pattern of the calcined CaBG material depicted in Figure 3a confirms its amorphous nature, in agreement with previous studies [79]. The pattern of the calcined SrBG, depicted in Figure $3 b$, shows some small peaks which are related to strontium silicate $\left(\mathrm{Sr}_{2} \mathrm{SiO}_{4}\right)$ and strontium carbonate $\left(\mathrm{SrCO}_{3}\right)$. The presence of strontium crystalline compounds like these in bioactive glasses was also reported by Solgi et al., who found out that the amorphous structure of bioactive glasses is altered by the incorporation of strontium $[80,81]$. In the low angle region (Figure 3, insets) the XRD patterns of both CaBG and SrBG show three diffraction peaks at $2 \theta$ ca. $2.4,4.2$ and $4.9^{\circ}$ which can be well indexed as (100), (110), and (200) reflections of the P6 mm hexagonal symmetry, and this suggests a well-ordered arrangement of pores in the prepared BGs [82-84]. 

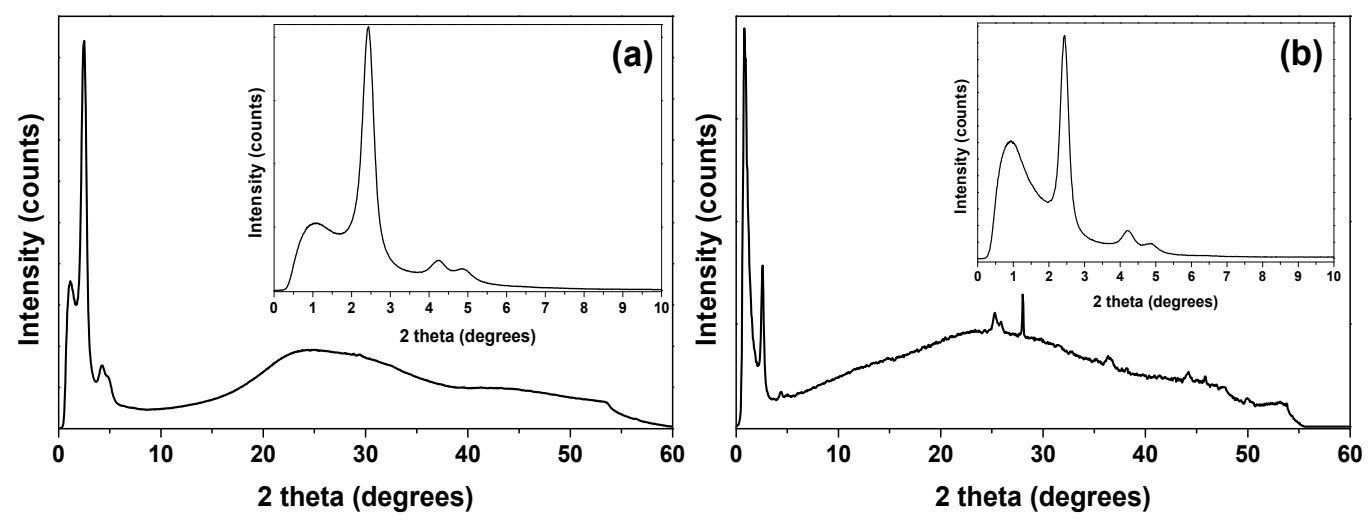

Figure 3. Wide- and low-angle XRD patterns of (a) CaBG and (b) SrBG BGs.

The pore properties of the calcined CaBG and SrBG samples were determined by analysis of their corresponding $\mathrm{N}_{2}$ adsorption/desorption isotherms at $77 \mathrm{~K}$ (Figure $4 \mathrm{a}, \mathrm{b}$ ), which, according to the classification of IUPAC are type IV, characteristic of mesoporous materials.
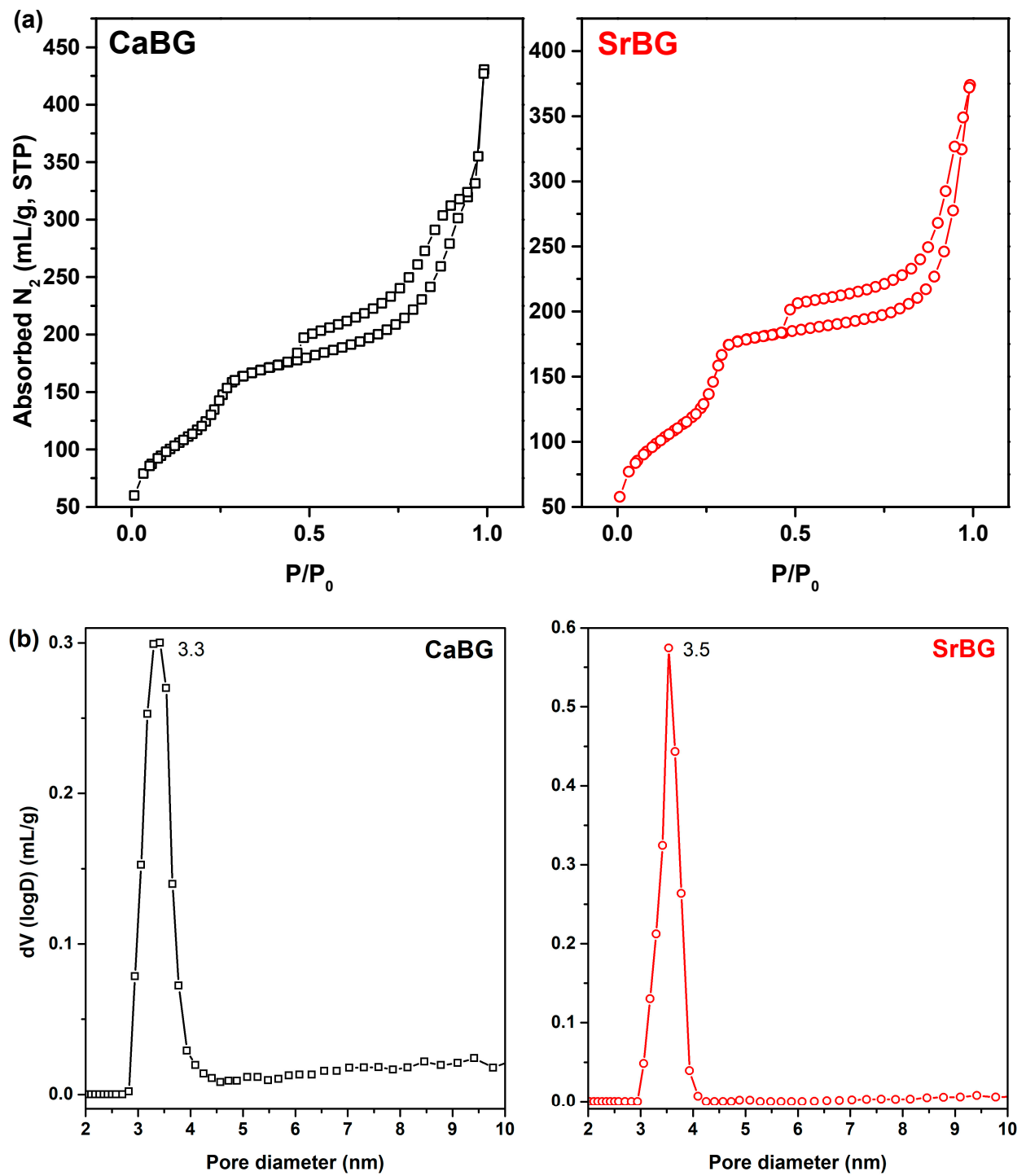

Figure 4. (a) $\mathrm{N}_{2}$ adsorption-desorption isotherms and (b) respective pore size distributions of CaBG and SrBG BGs. 
Overall CaBG was found to have a BET area of $588 \mathrm{~m}^{2} / \mathrm{g}$ and a total pore volume of $0.51 \mathrm{~cm}^{3} / \mathrm{g}$ (the latter calculated at $\mathrm{P} / \mathrm{P}_{0}=0.98$ ); the respective values for SrBG were $552 \mathrm{~m}^{2} / \mathrm{g}$ and $0.5 \mathrm{~cm}^{3} / \mathrm{g}$ (at $\mathrm{P} / \mathrm{P}_{0}=0.98$ ). In addition, the materials showed a mean pore size around $3.3-3.5 \mathrm{~nm}$ for the $\mathrm{CaBG}$ and $\mathrm{SrBG}$, respectively, according to the deduced pore size distributions (Figure 4c,d). The obtained specific surface area values are comparable to previous studies [85,86] and remarkably higher than those of conventional sol-gel glasses, allowing an improved reactivity in physiologic environment $[87,88]$.

Bioactivity of the BGs was assessed after immersion in SBF for 14 days. The FTIR spectra obtained are presented in Figure 5a. New absorption bands were observed around $540-601 \mathrm{~cm}^{-1}, 958 \mathrm{~cm}^{-1}$ and $1058 \mathrm{~cm}^{-1}$, which are characteristic of hydroxyapatite [75,89]. More specifically, the peaks at $540-601 \mathrm{~cm}^{-1}$ and $958 \mathrm{~cm}^{-1}$ are associated with the P-O bending mode of crystalline phosphate (apatite) deposited on the glasses, while the absorption band at around $1058 \mathrm{~cm}^{-1}$ is associated with the $\mathrm{P}-\mathrm{O}$ stretching mode [90]. Additionally, two peaks around 870 and $1401-1473 \mathrm{~cm}^{-1}$ attributed to $\mathrm{C}-\mathrm{O}$ stretching in carbonate groups were also observed [75]. The intensity of the peak around $1635 \mathrm{~cm}^{-1}$ increased after 14 days, which was attributed to the $\mathrm{OH}$ stretching mode [75]. The presence of $\mathrm{CO}_{3}{ }^{2-}$, $\mathrm{PO}_{4}{ }^{3-}$ and $\mathrm{OH}$ signals in the FTIR pattern can confirm the formation of hydroxyapatite on the surface of glasses after 14 days.

The XRD patterns of the CaBG and SrBG BGs after immersion in SBF solution for 1, 3, 7, and 14 days (Figure $5 \mathrm{a}, \mathrm{b}$ ) show characteristic peaks of hydroxyapatite and strontium apatite, verifying their bioactivity. Specifically, after soaking for one day, the patterns of both glasses show the existence of apatite peaks at $2 \theta=25.9^{\circ}, 2 \theta=27.3^{\circ}, 2 \theta=31.8^{\circ}$.
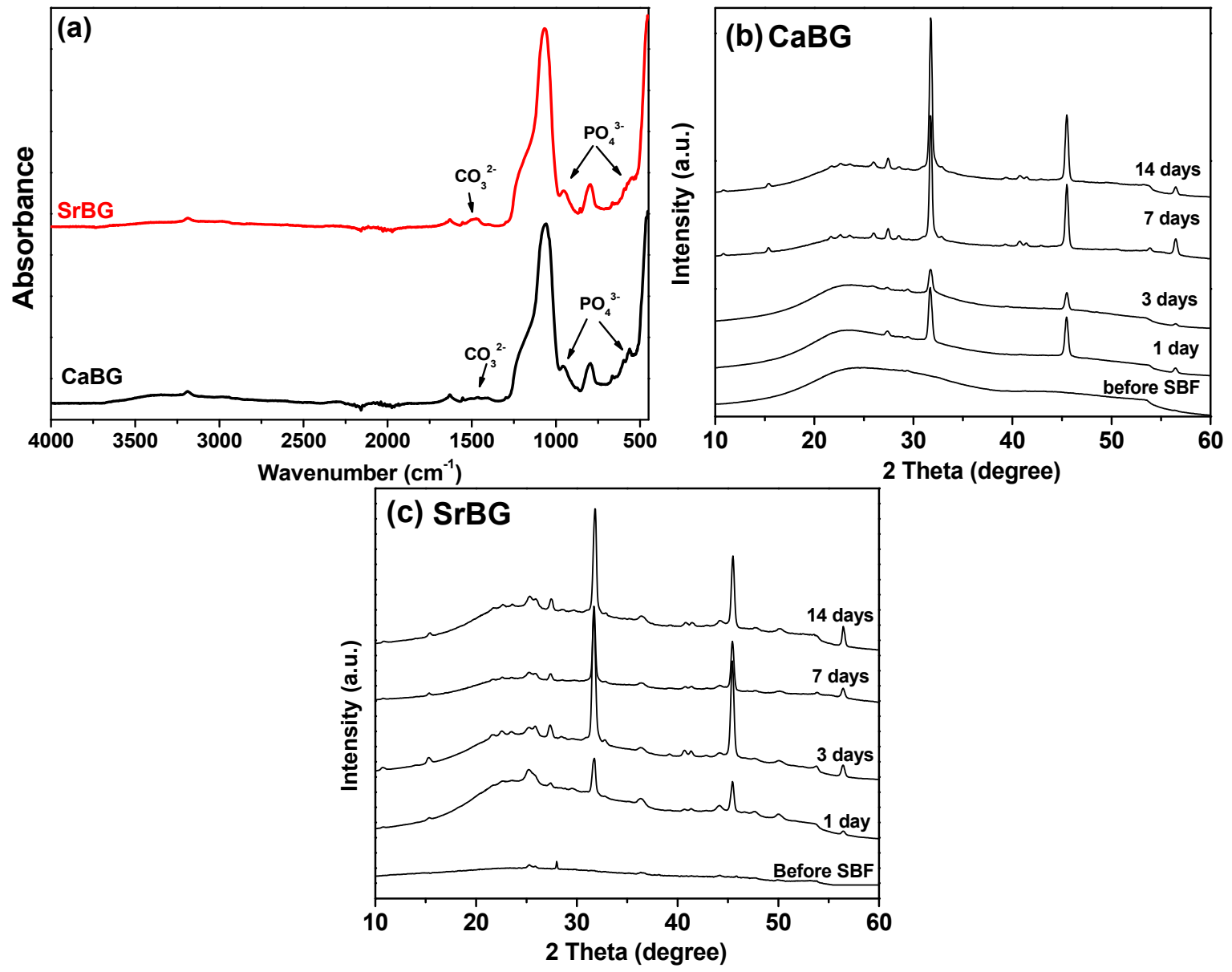

Figure 5. (a) FTIR spectra of the CaBG and SrBG BGs after immersion in SBF for 14 days, XRD patterns of (b) CaBG and (c) SrBG after immersion in SBF solution for 14 days. 
Nevertheless, it is observed that SrBG exhibits more and better visible features, especially in the area of $2 \theta=25.9^{\circ}, 2 \theta=27.3^{\circ}$ (Figure 5c) compared to CaBG. These results indicate the accelerating effect of $\mathrm{Sr}$ ions on the apatite formation ability of BGs, in agreement with previous studies on other BG systems [75,78,80,81,89,90].

The in vitro biocompatibility of $\mathrm{CaBG}$ and SrBG in two different concentrations in the cell culture medium (100 ug/mL and $200 \mathrm{ug} / \mathrm{mL}$ ) was tested by MTT assay, after seeding WJ-SCs on tissue culture polystyrene. After $24 \mathrm{~h}$, the viability of the cells was evaluated with fluorescence microscopy images (Figure 6a). The bright green spots are the viable cells that prove their successful adhesion and proliferation on both bioglasses. MTT assay results (Figure 6b) support the findings of the fluorescence microscopy results. More specifically, neither of the BGs affect the metabolic activity significantly, since the absorbance values are very close to that of the control WJ-SCs $(p>0.05)$. In the fluorescence microscopy micrographs, it appears that the cells proliferated continuously on the surface of the samples and formed cell-cell interactions and eventually a homogeneous cell layer.
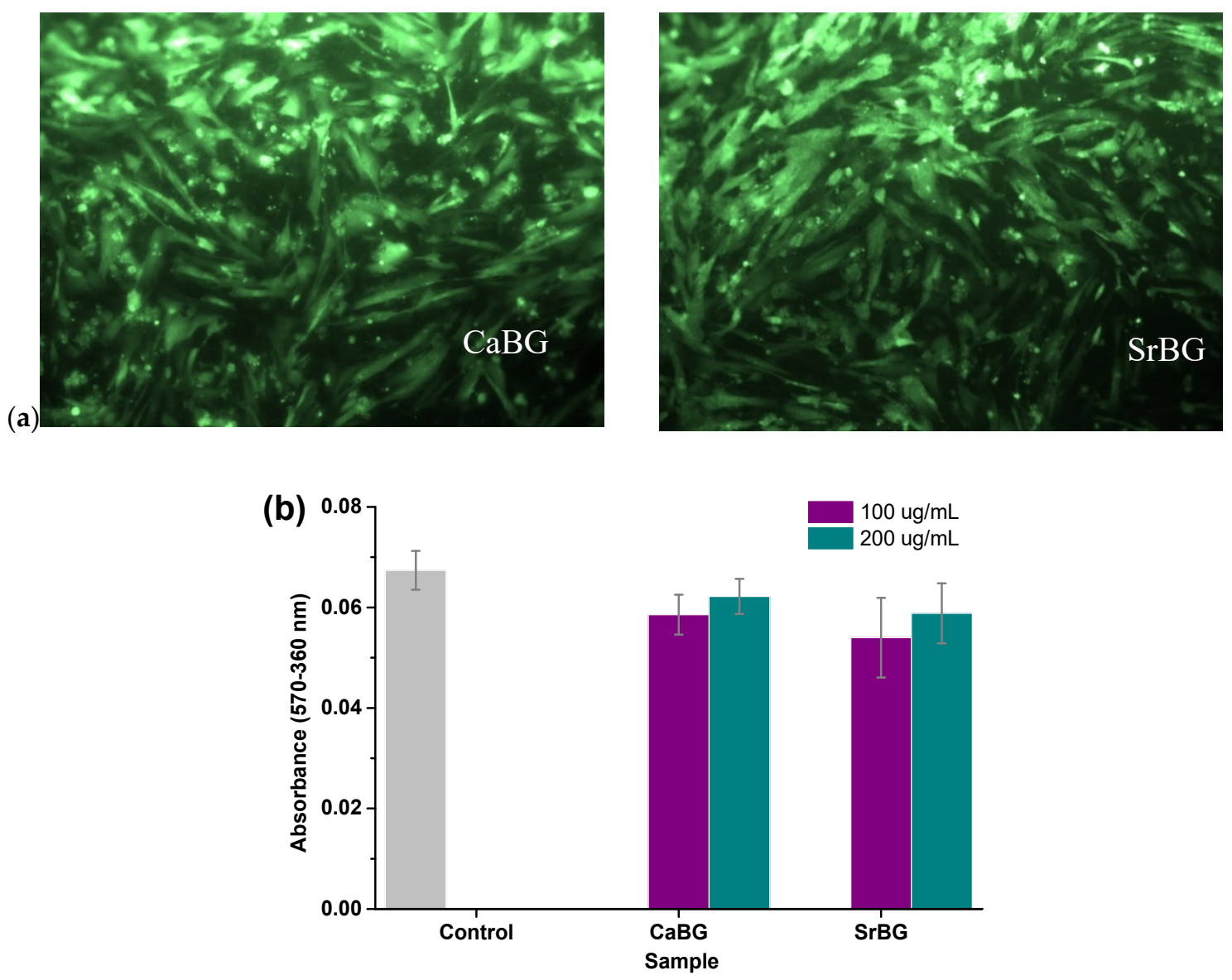

Figure 6. (a) Fluorescence microscopy micrographs of WJ-MSCs cells after exposure to CaBG and SrBG particles in the medium and (b) MTT assay results of WJ-MSCs cells after seeding for $24 \mathrm{~h}$ on CaBG and SrBG.

Adsorption of Iba on the Bioglasses

Mesoporous bioactive glasses with well-ordered mesopore structures, large surface area and pore sizes ranging from 5 to $20 \mathrm{~nm}$ that can be synthesized by sol-gel and hydrothermal methods can be easily loaded with different active compounds, making them ideal candidates for controlled drug delivery [91].

A preliminary in vivo study reported that the combination of the BP alendronate with BG led to increased bone formation on rats in comparison with the control groups [92]. A few years later, 
Rosenqvist et al. explored the physicochemical interactions of clodronate with BG based on the hypothesis that their beneficial impact originates not only from the pharmacological properties of the drug but also from the formation of a complex between them that creates a favorable environment for ion exchange [57].

The amount of Iba adsorbed on the pristine BGs was determined by TGA. The thermal stability of the as produced CaBG and SrBG BGs after calcination was confirmed by TGA and the results are presented in Figure 7. Both BGs exhibit two main weight loss steps. The first one with a $\mathrm{T}_{\max }$ at $105^{\circ} \mathrm{C}$ corresponds to loss of about 4.2 and 3.5\% physically adsorbed water for CaBG and SrBG, respectively. The second step occurs in the temperature range $200-800^{\circ} \mathrm{C}$. In general, both glasses are very thermally stable as expected, and lose $8 \%$ of their initial mass when heated to $800^{\circ} \mathrm{C}$.

The thermal degradation of Iba occurs in multiple stages $\left(180{ }^{\circ} \mathrm{C}, 254^{\circ} \mathrm{C}, 276{ }^{\circ} \mathrm{C}, 353^{\circ} \mathrm{C}, 423^{\circ} \mathrm{C}\right.$, $452^{\circ} \mathrm{C}$ ), while at $795^{\circ} \mathrm{C}$ there is a solid residue of $47.8 \%$. Based on the difference in mass loss of the BGs with and without $\mathrm{Iba}$, the amount of adsorbed drug was calculated at $3.78 \mathrm{wt} \%$ and $8.41 \mathrm{wt} \%$ for CaBG and SrBG, respectively. Similar drug loading adsorption capacities were reported in the bibliography for alendronate [93]. The drug loading capacity of SrBG is larger probably due to its slightly larger pores and the expansion of the glass network caused by the larger Sr ions compared to Ca.
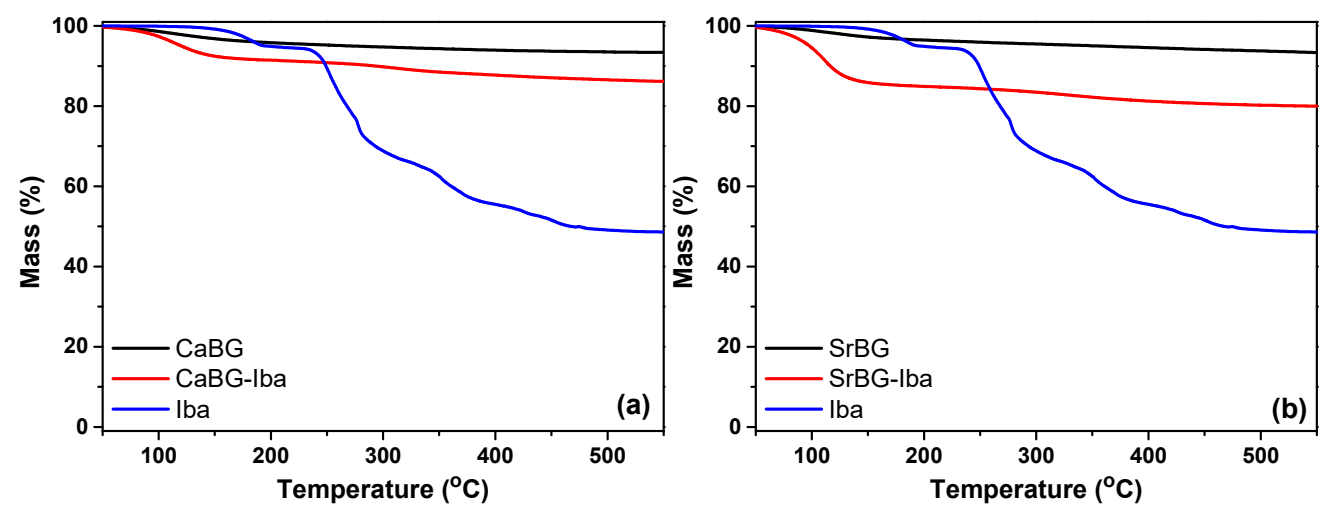

Figure 7. TGA thermograms of Iba and (a) CaBG, (b) SrBG before and after Iba adsorption.

Figure 8a shows the FT-IR spectra of Iba and CaBG and SrBG after Iba adsorption. The spectrum of Iba has a multitude of peaks; those in the spectral range $1200-900 \mathrm{~cm}^{-1}$ are due to the bending vibrations of the $\mathrm{CO}$ and $\mathrm{P}=\mathrm{O}$ groups [94], the peak at $1376 \mathrm{~cm}^{-1}$ is due to the vibration deformation of the methyl groups and the peak at $667 \mathrm{~cm}^{-1}$ is probably due to some type of stretching vibration of the phosphate groups [95].
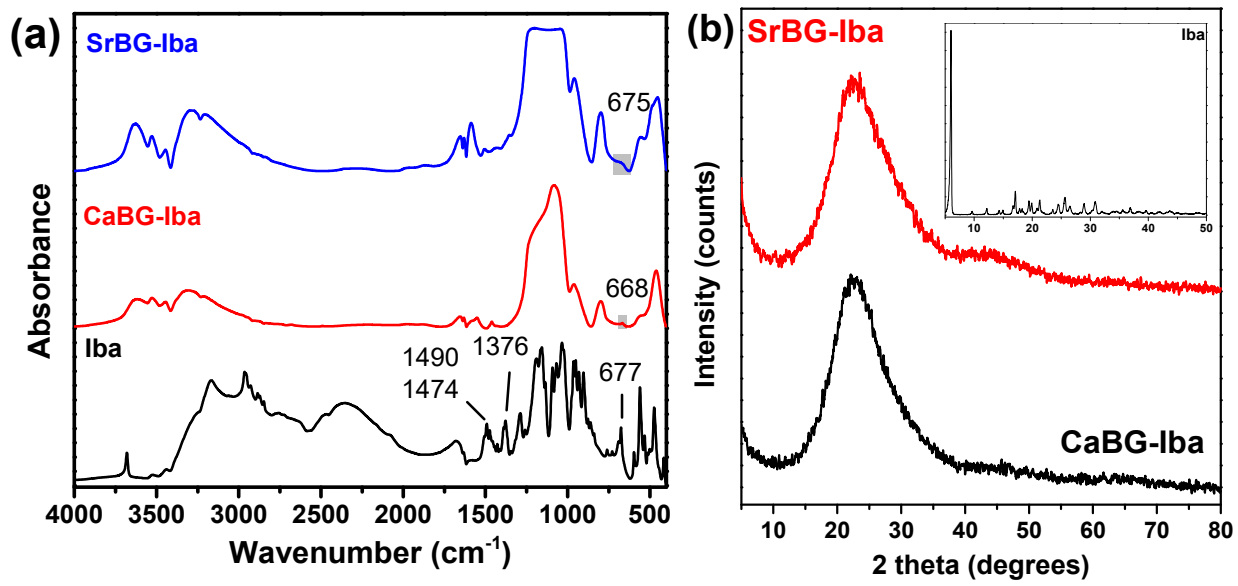

Figure 8. (a) FT-IR spectra of CaBG-Iba and SrBG-Iba and (b) X-ray diffraction patterns of Iba, CaBG-Iba and SrBG-Iba. 
After the incorporation of the drug, the FTIR spectra of the BGs present with some differences. The $677 \mathrm{~cm}^{-1}$ peak of Iba appears slightly shifted in the spectra of CaBG-Iba and SrBG-Iba, to $668 \mathrm{~cm}^{-1}$ and $675 \mathrm{~cm}^{-1}$ respectively, indicating the adsorption of the drug through the formation of strong bonds between the BGs and the phosphate groups of Iba.

XRD was used in order to examine how crystallinity of Iba is affected by its incorporation in the BGs. Iba itself shows many crystalline reflections, with the main located at $2 \theta=6^{\circ}$, while it is known that it is a polymorphic form [96]. However, the patterns of the CaBG-Iba and SrBG-lba show only one broad halo, as can be seen in Figure 8b, indicating that the adsorbed drug is in amorphous state. DSC thermograms of CaBG-Iba and SrBG-Iba during heating are presented in Figure S1 where no peak of Iba was detected, suggesting its amorphization, in agreement with the XRD results.

\subsection{Characterization of Composite PCL Thin Films}

\subsubsection{Morphological Characterization}

The basic methods used for the preparation of GTR membranes are solution casting, spin coating and electrospinning [5]. Spin coating is an inexpensive technique for uniform thin film fabrication that allows easy control of film thickness by altering the polymer concentration in the solution used [97]. All the prepared membranes covered the entire surface of the glass substrates homogenously and had a hazy appearance, suggesting that crystallization occurred during the spinning process. The thickness of the composite PCL/bioglass (with and without Iba) films deposited by spin coating on the glass slides was approximately 7.5-8 $\mu \mathrm{m}$ (whereas the neat PCL films were around $9 \mu \mathrm{m}$ ). The average mass and thickness values of the prepared membranes can be found in Table S2.

SEM analysis (Figure 9) showed that all membranes had a porous surface, most likely due to the fast evaporation of the solvent during spin coating [28]. This is a highly desirable feature for any material intended for tissue engineering applications, since surface porosity helps the adhesion and proliferation of cells. The pore size is smaller than the usual size of cells $(10 \mu \mathrm{m})$ so the prepared films could be used as occlusion membranes. In addition, all composite membranes exhibit a coarser structure than the smooth neat PCL film, due to the presence of the additives, which have also formed some aggregates. Bioglass ${ }^{\circledR}$ particles have been found capable of providing otherwise smooth polymeric films with surface irregularities [5]. Typically, spin coating of PCL solutions in chloroform gives smooth, flat and non-porous membranes [64,98,99], suggesting the final morphology of the film depends on the solvent used as well as on the subsequent thermal and/or vacuum treatment. Dziadek et al. recently confirmed this hypothesis, when they found that different solvents interact differently with PCL, creating solutions with unique features that result in polymeric films with controlled topography, crystallinity, mechanical properties and wettability [100].

\subsubsection{Structural Characterization}

The chemical structure of the prepared films was studied by FTIR spectroscopy (Figure S2). All peaks are attributed to stretching vibrations of the $\mathrm{C}-\mathrm{H}, \mathrm{C}=\mathrm{O}$ and $\mathrm{C}-\mathrm{O}$ bonds $[63,101]$. The absence of the hydroxyl peak is characteristic and is due to the high molecular weight of the synthesized PCL. The spectra of all composite membranes depict an additional small peak at $452 \mathrm{~cm}^{-1}$ associated with the vibrations of the $\mathrm{Si}-\mathrm{O}-\mathrm{Si}$ and $\mathrm{O}-\mathrm{Si}-\mathrm{O}$ bonds of the BGs. Otherwise, the absence of new peaks and/or shifts indicates the absence of strong interactions between the PCL matrix and the fillers [102]. 


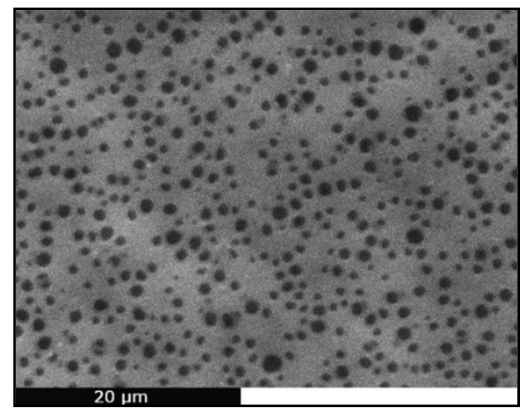

(a)

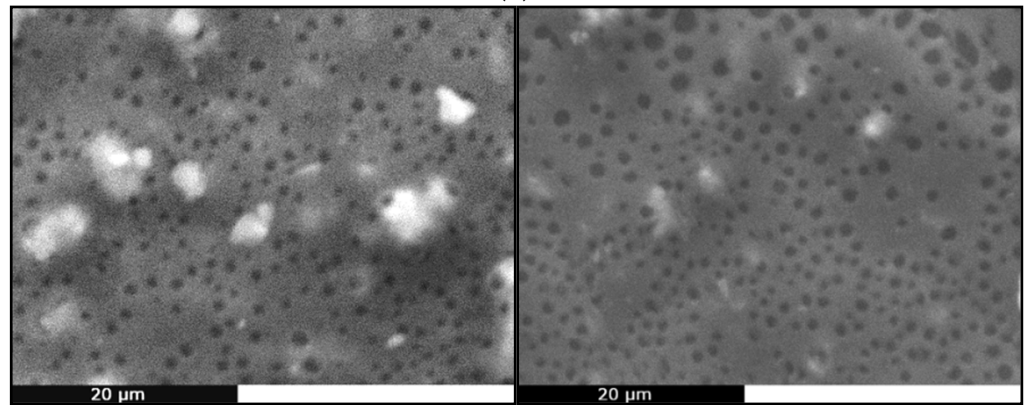

(b)

(c)

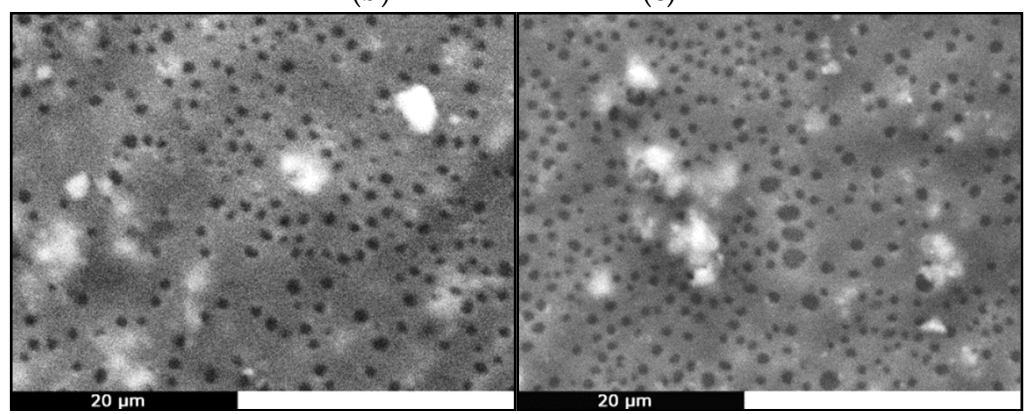

(d)

(e)

Figure 9. SEM micrographs of (a) PCL, (b) PCL/CaBG, (c) PCL/SrBG, (d) PCL/CaBG-Iba, (e) PCL/SrBG-Iba.

\subsubsection{Thermal Properties}

Table 2 shows the melting point, $\mathrm{T}_{\mathrm{m}}$, crystallization temperature, $\mathrm{T}_{\mathrm{c}}$, and crystallinity, $\mathrm{X}_{\mathrm{c}}$ values of PCL, Iba, and the respective composite films, as derived from DSC analysis. The respective DSC thermograms are presented in Figure S3. Iba is a polymorphic drug and this may explain the occurrence of two melting peaks, at $142{ }^{\circ} \mathrm{C}$ and $180^{\circ} \mathrm{C}$.

The neat PCL membrane has a $\mathrm{T}_{\mathrm{m}}=58.3^{\circ} \mathrm{C}$ and a crystallinity of $54.2 \%$, while the respective values for the bulk material are $65.4^{\circ} \mathrm{C}$ and $60 \%$ [63], indicating that the spin coating processing has a significant impact on the thermal properties of PCL. This effect may be directly related to the dissolution process and solvent evaporation, which even in very small quantities can act as a kind of plasticizer for the polymer, resulting to a lower $\mathrm{T}_{\mathrm{m}}$ and crystallinity. The composite membranes had quite similar $T_{m}$ and $T_{c}$ values with PCL. It should be noted that the thermograms of the PCL/CaBG-Iba and PCL/SrBG-Iba membranes did not show any drug-related peaks, which may indicate either its presence in an amorphous state, or its complete confinement in the pores of the BGs. The degree of crystallinity, however, decreased up to $22.5 \%$ in the presence of the bioactive glasses. 
Table 2. Thermal properties of PCL and its composite thin films.

\begin{tabular}{cccccc}
\hline Sample & Tm $\left({ }^{\circ} \mathbf{C}\right)$ & DHm $(\mathbf{J} / \mathbf{g})$ & Tc $\left({ }^{\circ} \mathbf{C}\right)$ & DHc $(\mathbf{J} / \mathbf{g})$ & Xc $(\mathbf{\%})$ \\
\hline Iba & $142.4,179.7$ & $173.64,25.90$ & - & - & \\
PCL & 58.3 & 73.16 & 34.7 & -57.96 & 54.2 \\
PCL/CaBG & 57.5 & 53.81 & 35.1 & -47.40 & 35.9 \\
PCL/SrBG & 58.5 & 50.83 & 34.6 & -43.04 & 33.9 \\
PCL/CaBG-Iba & 59.2 & 47.60 & 34.8 & -39.81 & 31.7 \\
PCL/SrBG-Iba & 59.4 & 54.75 & 34.1 & -51.06 & 36.5 \\
\hline
\end{tabular}

Addition of bioactive glass particles with sizes larger than $3 \mu \mathrm{m}$ has been reported to decrease the $T_{m}$ and $X_{c}$ of PCL and this reduction has been attributed to the formation of defective crystals and hindering of macromolecular chain mobility $[100,103]$, while on the contrary BGs with diameter $<1 \mu \mathrm{m}$ seem to have a beneficial effect on the thermal properties and crystallinity of the membrane. Another important factor that has great impact on thermal properties are the interfacial interactions between the polymeric matrix and the filler [104]. In a recent work of our group it was concluded that the synthesis of PCL nanocomposites with different nanosized mesoporous BGs resulted in strong interfacial interactions between the polymer and the fillers which had a great impact on improvement of thermal properties [63]. Thermal stability of the films was studied by TGA (Figure S4). PCL is a fairly thermally stable polymer that degrades in one step at a $\mathrm{T}_{\max }$ of $420^{\circ} \mathrm{C}$. This is shifted to lower temperatures by about $10{ }^{\circ} \mathrm{C}$ in the composite $\mathrm{PCL} /$ bioglass films, indicating their lower thermal stability. According to literature, bioglass particles dramatically reduce the thermal stability of biodegradable polymers, because of the hydroxyl groups on the particle surface. These groups, in the presence of moisture, can be linked to the $\mathrm{Ca}^{2+}$ counter-ion catalyzing chain cleavage effects [105]. Nevertheless, the PCL/CaBG-Iba and PCL/SrBG-Iba films have slightly better thermal stability than those without Iba.

\subsubsection{Mechanical Properties}

The loading-unloading indentation curves of neat PCL, PCL/SrBG and PCL/CaBG as well as those loaded with Iba (PCL/SrBG-Iba and PCL/CaBG-Iba) are shown in Figure S5. The indentation force-depth curves for all materials under test specified a creep phenomenon at the peak force of $10 \mathrm{mN}$. PCL has shown larger creep than the composite membranes, while all loading and unloading curves have shown no discontinuities or steps, indicating that no cracks were formed during indentation. The indentation depths at the peak load range approximately between 1.7-2.2 $\mu \mathrm{m}$ for the PCL composites and around $3.2 \mu \mathrm{m}$ for the neat PCL. The plastic work done was significantly higher for PCL, as revealed from the increased area enclosed between the loading and unloading curve. On the contrary, that softening behavior was not observed in the loading-unloading response of all composite membranes. In addition, the PCL/SrBG-Iba has shown the lowest indentation depth as compared with all other materials under study.

Figure 10 shows the results from the indentation test. The modulus of neat PCL was $797 \mathrm{MPa}$, while the elastic modulus of PCL/SrBG-Iba was the highest obtained as compared to the results from the other materials under study with a value of $5784 \mathrm{MPa}$. The indentation hardness measurements followed the same pattern, with a small hardness increase by the addition of Iba with the highest values obtained for PCL/CaBG-Iba. As expected, the addition of BGs in the PCL films resulted in a statistically significant increase in the indentation hardness as well as in the elastic modulus. The differences between the composite membranes were insignificant. 

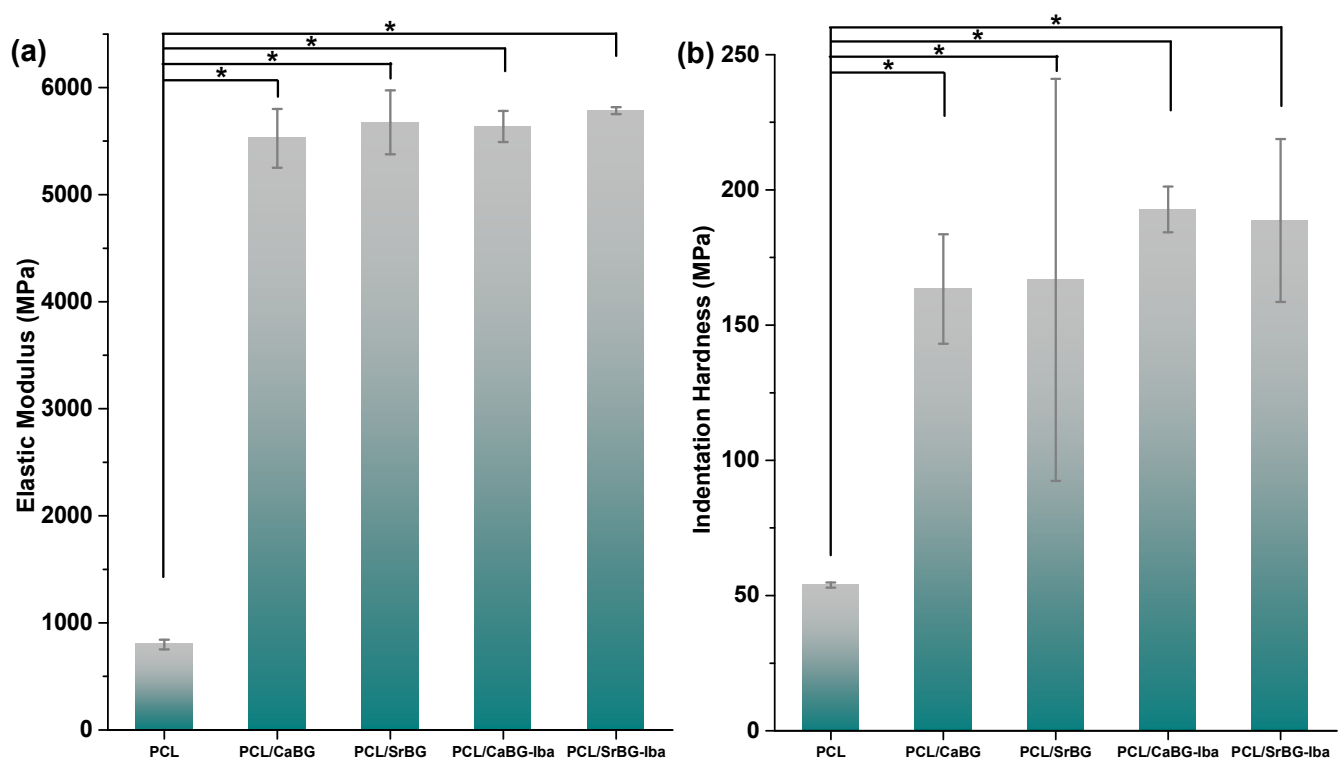

Figure 10. (a) Elastic Modulus and (b) Hardness of PCL membranes. *: $p<0.05$.

\subsubsection{Hydrophilicity}

One of the most important parameters for enabling adequate adhesion and cell proliferation on the surface of a material is its hydrophilicity. PCL, although biodegradable and bioresorbable, is hydrophobic and as a result it degrades slowly. A simple and effective method for increasing the hydrophilicity of PCL is the introduction of hydrophilic particles such as BGs. BG particles have been reported to increase the hydrophilicity and water sorption properties of $\mathrm{PCL}$, allowing the tailoring of the degradation rate of the polymer in physiological environment [106].

Water contact angle measurements showed a contact angle of $91.5^{\circ}$ for neat PCL (Figure 11). After the introduction of $\mathrm{CaBG}$ and SrBG particles this value drops to about $82^{\circ}$, due to the hydrophilic character of the two additives [106]. The contact angle decreases even further, and the membranes become even more hydrophilic after the incorporation of Iba loaded BGs, which was expected since the drug is freely soluble in water.

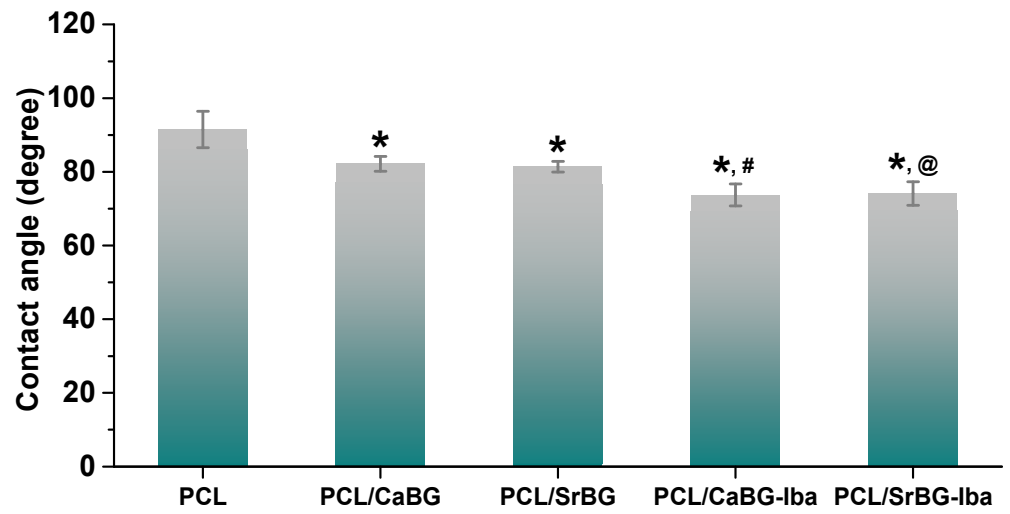

Figure 11. Water contact angle values of composite thin films. * $p<0.05$ compared to PCL, \# compared to PCL/CaBG, @ compared to PCL/SrBG.

\subsubsection{In Vitro Bioactivity}

Apatite deposition is necessary for the formation of a bioactive interface between biomaterials and tissues, since it can promote the proliferation and differentiation of osteoblasts [48]. Bioactivity is one of the most attractive features of BGs, since their incorporation in bioinert polymeric matrices can impart on them significant bioactivity $[106,107]$. 
In vitro bioactivity of the PCL membranes was investigated by immersing them in SBF for 14 days followed by observation of their surface by SEM and EDX spectra (Figure 12). As expected, no hydroxyapatite was formed on the surface of neat PCL, which is considered a bioinert material. In contrast, scattered spherical particles with a composition similar to that expected for hydroxyapatite were observed on the surface of the composite films. The addition of SrBG seems to enhance more the bioactivity of PCL than CaBG, in agreement with the bioactivity testing of the standalone bioglasses (Figure 5).

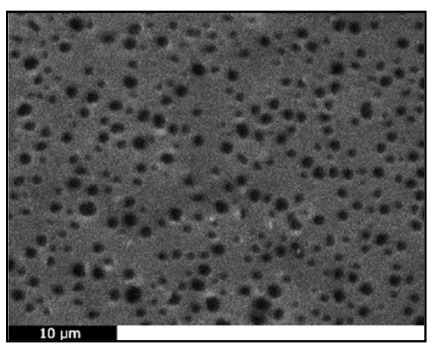

PCL

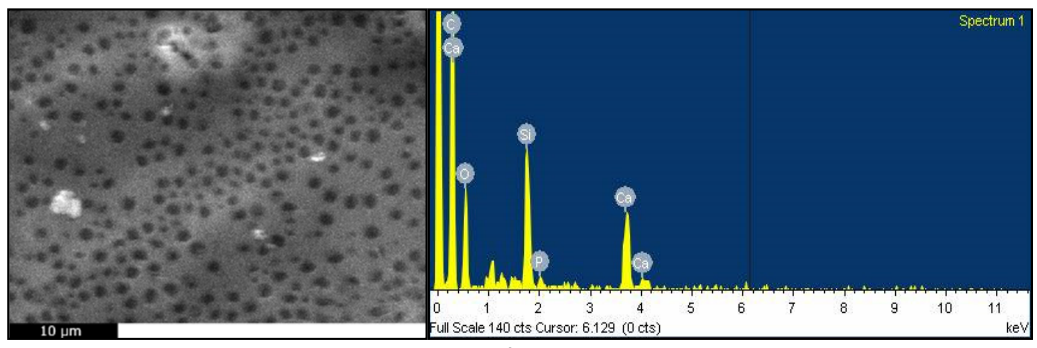

PCL/CaBG

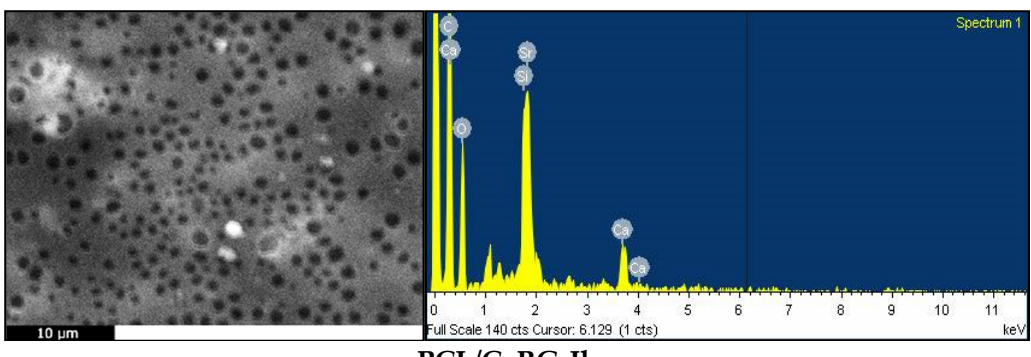

PCL/CaBG-Iba

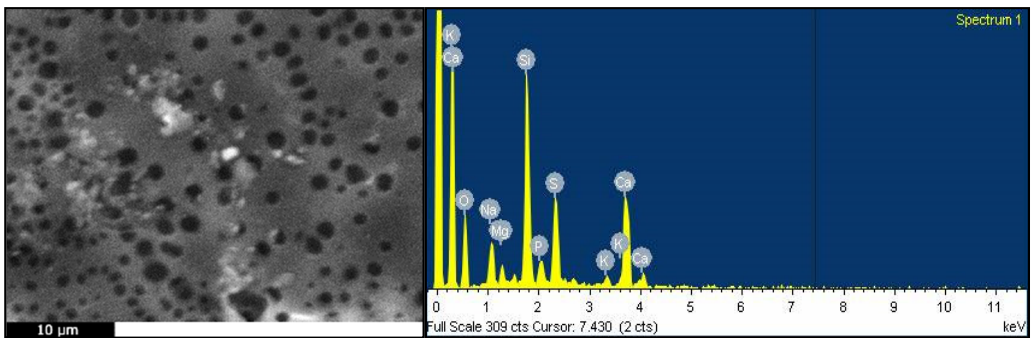

PCL/SrBG

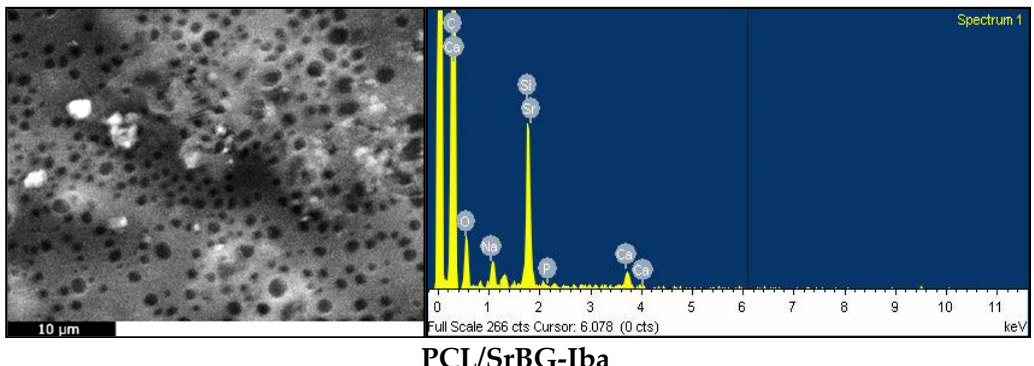

Figure 12. SEM images and EDX spectra of PCL and its composite thins films before and after 14 days of soaking in SBF. 
The number of these particles increases in the presence of Iba for both PCL/CaBG-Iba and PCL/SrBG-Iba membranes, suggesting that Iba further enhances the bioactivity of PCL membranes.

\subsubsection{Ion Release}

Testing of bioactivity in SBF provides with useful preliminary results, but ionic dissolution products and their concentration are also essential for stimulating the growth and differentiation of osteoblasts [108]. Therefore, the amounts of $\mathrm{Si}, \mathrm{Ca}, \mathrm{P}$ and $\mathrm{Sr}$ released when the BGs and the PCL membranes were exposed to SBF for 30 days were quantified with ICP-MS. The results are shown in Figure 13. The respective measurements showed an increasing release of $\mathrm{Si}$ ions (Figure 13a) with time for all samples (pristine BGs and composite films). Changes in the concentrations of ions during incubation of BG containing samples in SBF is a result of both dissolution and precipitation. Initially, ion concentrations are expected to increase due to dissolution of the BGs, followed by precipitation of apatite or amorphous calcium phosphate that cause their consumption from the solution $[109,110]$.

Concentration of Si increased continuously with immersion duration (Figure 13a). When in contact with SBF, cation exchange between the buffer solution and the BGs takes place. This cation exchange results in the formation of $\mathrm{Si}-\mathrm{OH}$ groups that increase the $\mathrm{pH}$, which in turn results in cleavage of $\mathrm{Si}-\mathrm{O}-\mathrm{Si}$ bonds, therefore releasing $\mathrm{Si}$ ions in the solution. The amount as well as the release rate of Si was higher for the samples with Sr-substituted BG compared to CaBG, as the BGs with Sr have a more expanded network and thus are more soluble in aqueous solutions [111,112].
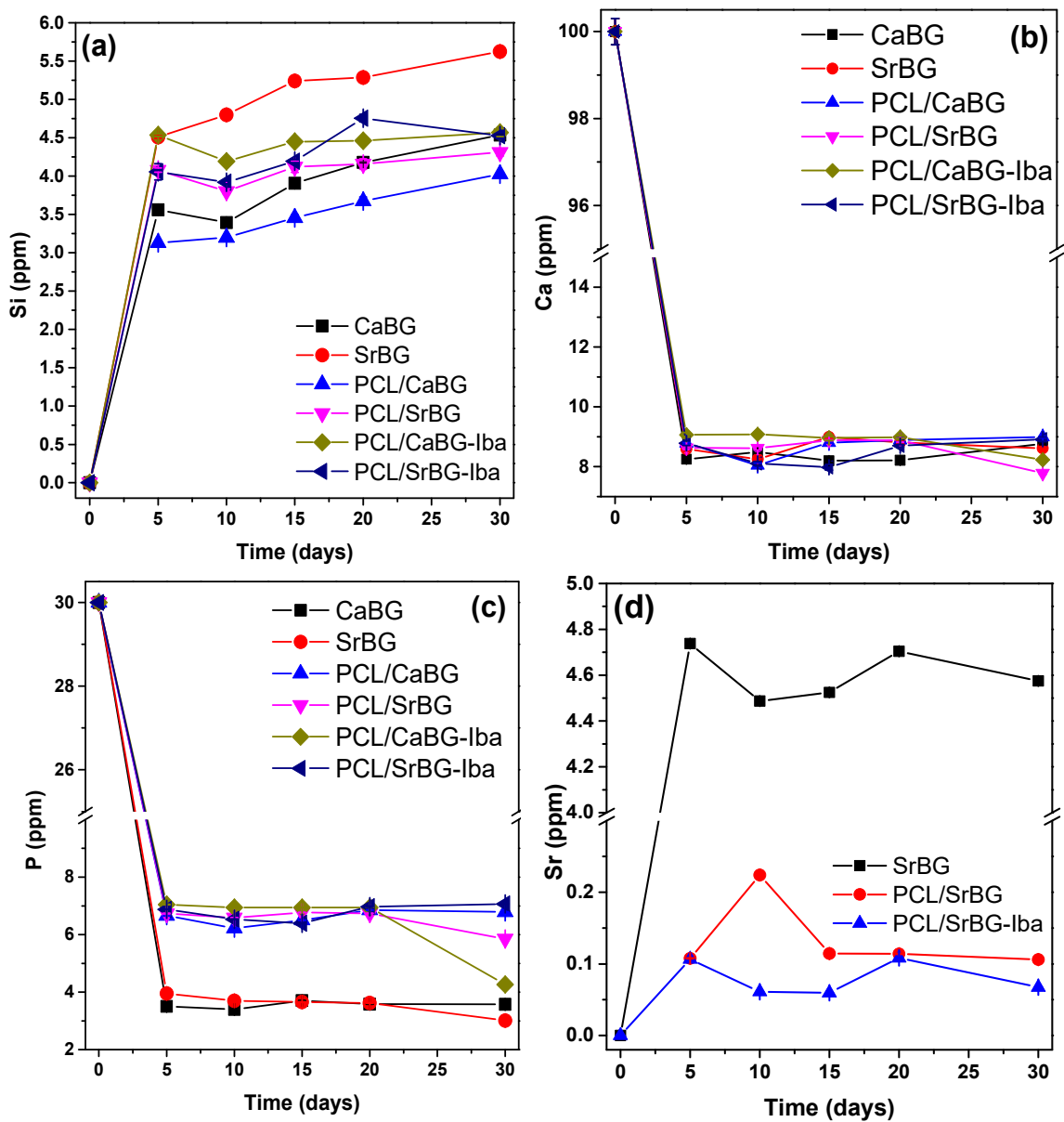

Figure 13. Release of (a) Si, (b) Ca, (c) P and (d) Sr ions from composite PCL films and pristine CaBG and SrBG BGs.

A large amount of $\mathrm{P}$ and $\mathrm{Ca}$ ions is consumed during the first 5 days of immersion of the samples in SBF, as shown in Figure 13b,c. During biomineralization of the surface of bioactive materials, 
a CaO- $\mathrm{P}_{2} \mathrm{O}_{5}$ layer is formed after the migration of $\mathrm{PO}_{4}{ }^{3-}$ and $\mathrm{Ca}^{2+}$ ions from SBF [43], resulting in decrease of the concentration of $\mathrm{P}$ and $\mathrm{Ca}$. The consumption of both $\mathrm{Ca}$ and P from CaBG and SrBG occurred at an almost identical extend suggesting their bioactivity is very similar, which is in agreement with the FTIR and XRD measurements of Figure 5. These results highlight the fact that the total substitution of Ca with Sr does not negatively affect the bioactivity of the BG.

In all cases, biomineralization seems to have taken place already during the first 5 days of incubation for both the BG powders as well as the membranes. After the 20th day, a new reduction in the concentration of $\mathrm{Ca}$ and $\mathrm{P}$ ions is observed for most samples which is indicative of the formation of amorphous calcium phosphate (ACP) during the $4^{\text {th }}$ step of hydroxyapatite formation [113].

In the case of $\mathrm{Sr}$, the amounts released are relatively stable with time indicating rapid initial release. The concentration of $\mathrm{Sr}^{2+}$ released from $\mathrm{SrBG}$ is approximately $4.5 \mathrm{ppm}$, while the SrBG containing membranes released $\mathrm{Sr}$ ions in the range of $\mathrm{ppb}$. It is well known that the beneficial effect of $\mathrm{Sr}$ ions on osteoblasts is dose dependent. It has been reported that $\mathrm{Sr}^{2+}$ concentrations from 8.7 to 87.6 ppm have a stimulatory effect on osteoblasts in vitro [114], while larger amounts result to apoptosis [115].

\subsubsection{In Vitro Cytocompatibility and Osteogenic Potential}

WJ-MSCs, easily isolated from cord tissue during birth, consist one of the most common stem cell sources for induced differentiation assays. The biocompatibility of PCL and its composite films incorporating CaBG/CaBG-Iba and SrBG/SrBG-Iba was evaluated by seeding WJ-MSCs on the surface of the materials. Cell viability was assessed after $24 \mathrm{~h}$ with fluorescence microscopy, as presented in Figure 14a.

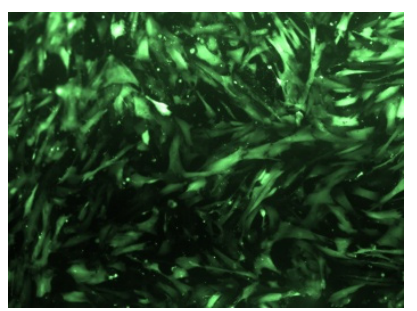

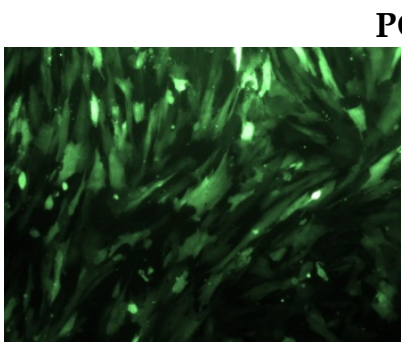

PCL/CaBG

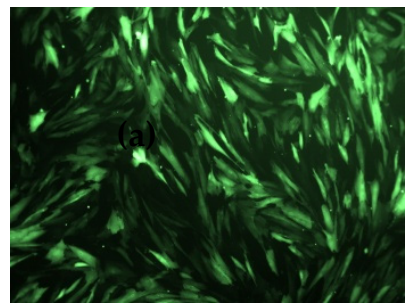

PCL/CaBG-Iba
PCL

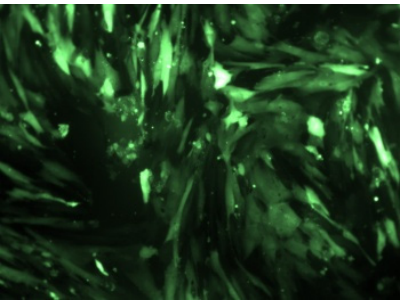

PCL/SrBG

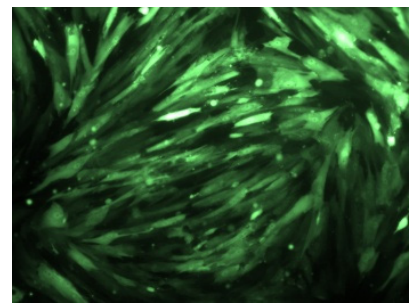

PCL/SrBG-Iba

(a)

Figure 14. Cont. 

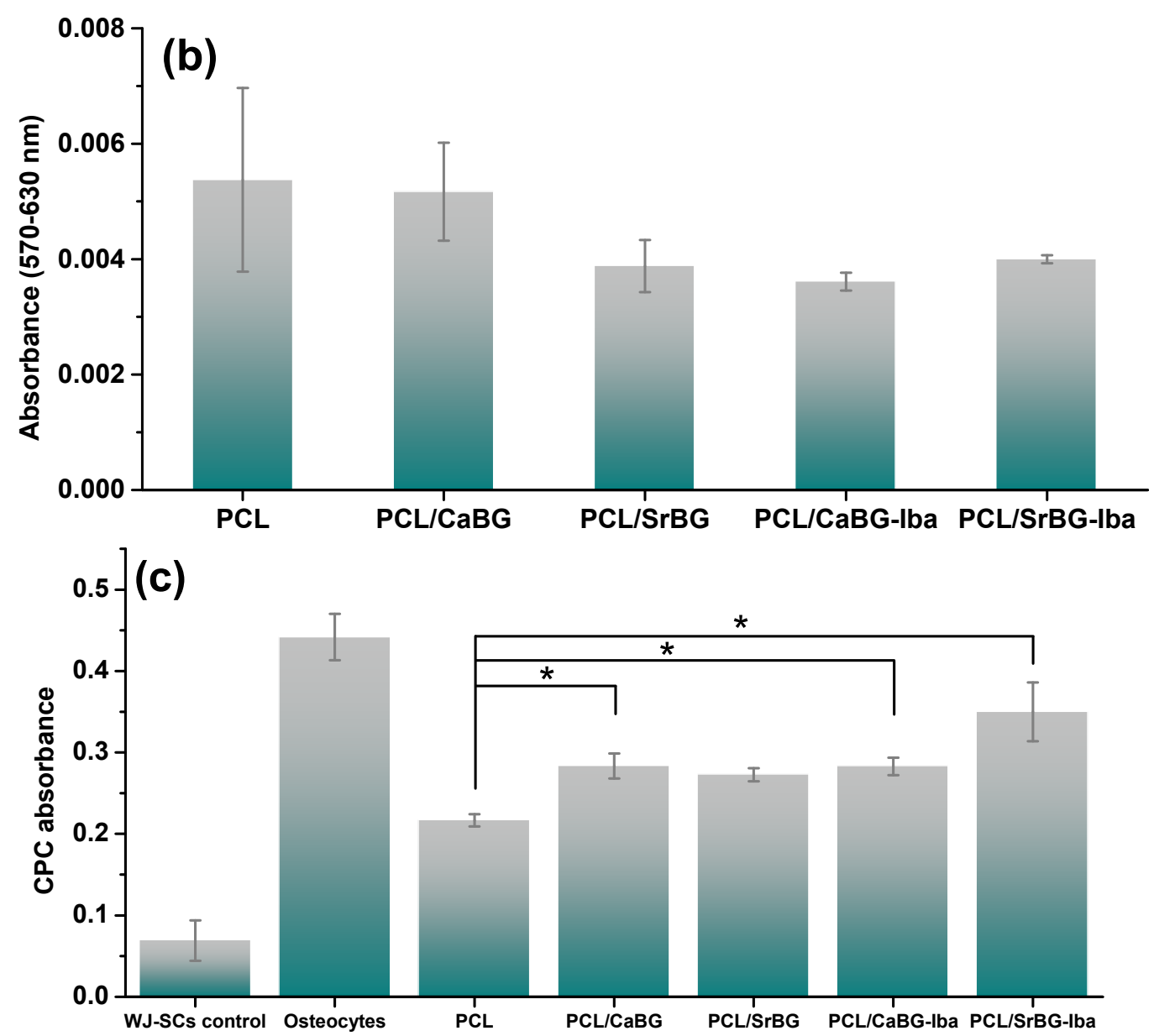

Figure 14. (a) Fluorescence microscopy images of genetically modified WJ-MSCs on the PCL membranes, (b) MTT assay results of WJ-MSCs cells after seeding for $24 \mathrm{~h}$ on PCL and its nanocomposites and (c) assessment of osteogenic differentiation by cetylpiridinium chloride (CPC) method after 28 days in the induced-differentiation culture 30 days culture. *: $p<0.05$.

In all cases, no cytotoxicity was observed after $24 \mathrm{~h}$. The viable cells appear as bright green spots that adhered and grew on all films. Fluorescence microscopy findings were further supported by MTT assay results (Figure 14b). The performed t-test proved that there are no significant differences in the metabolic activity of the films, thus demonstrating the viability of the cells. None of the films appeared to cause cytotoxicity (since the Sr content in the PCL/ SrBG and PCL/SrBG-Iba films was too small-in the ppb range as already shown in Figure 13-to have any cytotoxic effect). This is confirmed by the fluorescence micrographs, with the cells adhering and multiplying on the film's surfaces, indicating their biocompatibility.

The osteogenic differentiation of WJ-MSCs to osteocytes on PCL and its nanocomposites was evaluated using the cetylpiridinium chloride (CPC) method after 30 days of induced cell culture towards osteocytes [116]. As shown in Figure 14c, WJ-MSCs attached to the PCL/SrBG-Iba sample presented the highest differentiation potential to osteocytes in comparison with neat PCL, which could possibly be attributed to the synergistic effect of $\mathrm{Sr}$ and Iba on osteogenesis. It is noteworthy that the cellular attachment on PCL, instead of the plastic surface of the culture plates, reduces their effective differentiation to osteocytes as evidenced by the stronger differentiation of the control group WJ-SCs (negative control) to osteocytes (positive control). However, the incorporation of osteoinductive additives in PCL matrices seems to facilitate the osteoinductive medium mediated-differentiation statistically significant compared to the PCL group. 
Recently, PCL-based scaffolds containing osteoinductive molecules were developed for accelerated or enhanced osteogenic differentiation and bone tissue regeneration [58]. On this basis, the incorporation of Sr-containing BGs in combination with bisphosphonates in PCL seems to be an effective strategy to modulate its osteogenic potential and possibly stimulate osteogenic differentiation. The incorporation of osteoinductive additives in PCL matrices could promote bone tissue formation by avoiding the introduction of osteoinductive mediums in cell cultures, with the goal of minimizing the addition of exogenous growth factors. The use of non-cytotoxic materials as mediators of induced differentiation towards a desirable tissue could widen the applications of biomaterials in regenerative medicine.

\section{Materials and Methods}

\subsection{Materials}

$\varepsilon$-Caprolactone (CL) monomer (purity 99\%), tin(II) 2-ethylhexanoate (TEH) catalyst (analytical grade), poly(ethylene glycol) (PEG) (average Mn $10.000 \mathrm{~g} / \mathrm{mol}$ ), tetraethyl orthosilicate (TEOS) (reagent grade $98 \%$ ), triethyl phosphate (TEP) (purum $99.8+\%$ ), calcium nitrate tetrahydrate $\mathrm{Ca}\left(\mathrm{NO}_{3}\right)_{2} \cdot 4 \mathrm{H}_{2} \mathrm{O}$ ) (ACS reagent $99 \%$ ), $\mathrm{Sr}\left(\mathrm{NO}_{3}\right)_{2}$ (ACS reagent, $\geq 99 \%$ ), cetyltrimethylammonium bromide (CTAB) and ethanol were purchased from Sigma Aldrich Chemical Company (Saint Louis, MO, USA). Sodium hydrate pellets were supplied from Mallinckrodt Company (Staines-upon-Thames, UK). Ibandronate API (Iba) was kindly donated by Pharmathen SA (Athens, Greece).

\subsection{Synthesis of Mesoporous Ternary Bioglasses}

Two different types of mesoporous ternary BGs $\left(\mathrm{SiO}_{2}-\mathrm{CaO} / \mathrm{SrO}-\mathrm{P}_{2} \mathrm{O}_{5}\right)$ were prepared through a hydrothermal method based on a previously described protocol [63], using PEG and CTAB, as non-ionic co-surfactant and cationic surfactant, respectively. $\mathrm{CaO}$ was fully replaced by $\mathrm{Sr}$ ( $10 \%$ on molar ratio). Briefly, for the preparation of the ternary bioglass with $80 \% \mathrm{SiO}_{2}, 10 \% \mathrm{SrO}, 10 \% \mathrm{P}_{2} \mathrm{O}_{5}$ molar ratio (hereafter denoted as SrBG), proper amounts of PEG and sodium hydrate were dissolved in distilled $\mathrm{H}_{2} \mathrm{O}$ under vigorous stirring, followed by the addition of CTAB. After stirring for $1 \mathrm{~h}$ at room temperature, $\mathrm{Sr}\left(\mathrm{NO}_{3}\right)_{2}$, TEOS and TEP were added to the mixture, which was kept at room temperature under vigorous stirring for $24 \mathrm{~h}$ and then transferred into Teflon-lined autoclaves. The autoclaves were sealed and heated at $80^{\circ} \mathrm{C}$ for $48 \mathrm{~h}$ and then allowed to cool down to room temperature. The reaction products were obtained by filtration after washing with $\mathrm{H}_{2} \mathrm{O}$ and ethanol and drying at $100{ }^{\circ} \mathrm{C}$ overnight. Finally, the white powder obtained was calcined in air at $600{ }^{\circ} \mathrm{C}$ for $5 \mathrm{~h}$ with a heating rate of $9{ }^{\circ} \mathrm{C} / \mathrm{min}$. The same protocol, with the necessary adaptations, was also followed to obtain the Ca-containing bioglass systems (hereafter denoted as $\mathrm{CaBG}$ ), in which $\mathrm{Ca}\left(\mathrm{NO}_{3}\right)_{2} \cdot 4 \mathrm{H}_{2} \mathrm{O}$ precursor was used as a calcium source.

\subsection{Synthesis of PCL via Ring Opening Polymerization (ROP)}

PCL was synthesized with the ring opening polymerization (ROP) of $\varepsilon$-caprolactone $(\varepsilon-C L)$ monomer, based on a previously described protocol [63]. More specifically, $\varepsilon-\mathrm{CL}$ was dried over $\mathrm{CaH}_{2}$ and purified by distillation under reduced pressure prior to use. The bulk polymerization of $\varepsilon$-CL was carried out in a $250 \mathrm{~mL}$ round-bottom flask equipped with a mechanical stirrer and a vacuum apparatus. The catalyst TEH was added as a solution in toluene at a final concentration of $1 \times 10^{-4}$ mol per mol of monomer and the mixture was degassed and purged with dry Ar. The reaction was carried out for $3 \mathrm{~h}$ at $190{ }^{\circ} \mathrm{C}$, followed by increasing the reaction temperature from 210 to $240{ }^{\circ} \mathrm{C}$ over a period of $90 \mathrm{~min}$. Monomers were removed through distillation by gradually applying high vacuum $(\approx 5 \mathrm{~Pa})$, to avoid excessive foaming. Polymerization was terminated by rapid cooling to room temperature. Molecular weight per weight, as measured by gel permeation chromatography, had a value of $71900 \mathrm{~g} / \mathrm{mol}$ and a polydispersity index of 1.49 [63]. 


\subsection{Loading of $C a B G$ and SrBG Bioglasses with Ibandronate}

CaBG and SrBG were loaded with Iba (denoted as CaBG-Iba and SrBG-Iba, respectively), through the following procedure. $500 \mathrm{mg}$ of each bioglass was dispersed in a $0.5 \mathrm{wt} \%$ aqueous solution of the drug under magnetic stirring for 3 days. Each dispersion was finally centrifuged at $4000 \mathrm{rpm}$ and the obtained solid was dried under vacuum.

\subsection{Preparation of PCL Composite Thin Films with Bioglasses}

Both bare and drug loaded bioglass particles were combined with PCL for the preparation of composite thin films by spin coating (Model WS-650MZ-23NPPBO, Laurell Technologies Corporation, North Wales, PA, USA). Before the experiments, glass slides with dimensions $2 \times 2 \mathrm{~cm}$ and thickness 0.13-0.17 mm were cleaned with acetone, rinsed with deionized water and dried under a nitrogen purge. After systematic spin coating trials using a $10 \mathrm{wt} \%$ PCL solution in dichloromethane, the optimum rotation speed of $6000 \mathrm{rpm}$ and a volume of $0.6-0.7 \mathrm{~mL}$ for each sample was used. These conditions were employed for the preparation of the composite films, using as feed a dispersion of both BGs (with and without Iba) in the PCL solution at a concentration of $10 \mathrm{wt} \%$ (with respect to the total PCL mass). The fillers were dispersed in the solution with an ultrasonic probe. A continuous flow of nitrogen and vacuum were used during processing, which resulted in four composite materials, i.e., the drug-free PCL/CaBG, PCL/SrBG and those incorporating Iba, PCL/CaBG-Iba and PCL/SrBG-Iba. Neat PCL thin films were also prepared and used as reference. After the spinning process, the coated glass slides were stored in a fume hood while allowing the solvent to evaporate for $24 \mathrm{~h}$ and were finally dried under vacuum oven at $30^{\circ} \mathrm{C}$ for $24 \mathrm{~h}$ to remove any residual solvent.

\subsection{Characterization}

\subsubsection{Characterization of CaBG and SrBG}

The morphological features of the BGs were assessed through a Phenom ProX (Phenol-World BV, Eindhoven, The Netherlands) scanning electron microscope (SEM) equipped with an energy-dispersive X-ray. The samples were attached on a metal stub with double-sided carbon tape (Ted Pella Inc, Redding, CA, USA) and inserted in the scanning electron microscopy's vacuum chamber using a special charge reduction sample holder. This sample holder is designed to reduce sample charging and eliminate extra sample preparation of non-conductive samples. The morphology of the membranes was examined with a JMS-840A SEM instrument (JEOL, Akishima, Japan) equipped with an energy-dispersive X-ray Oxford ISIS 300 microanalytical system (Oxford Instruments, Tubney Woods, Abingdon, UK). All samples were coated with carbon black to avoid charging under the electron beam.

Particle size distribution of the prepared nanoparticles was determined by dynamic light scattering (DLS) using a Zetasizer Nano instrument (ZEN 3600; Malvern Instruments, Malvern, Worcestershire, UK) operating with a $532 \mathrm{~nm}$ laser. A suitable amount of each BG was dispersed in distilled water to a final concentration of $1 \%$ and was ultrasonicated before the measurement. For each sample, three measurements were conducted.

Fourier transform infrared spectroscopy (FTIR) spectra of the BGs before and after Iba adsorption were obtained using a model Spectrum One FTIR spectrometer (Perkin-Elmer, Waltham MA, USA).

The powder X-ray diffraction (XRD) patterns of the BGs were recorded on a Rigaku R-AXIS IV Imaging Plate Detector mounted on a Rigaku RU-H3R Rotating Copper Anode X-ray Generator $(\lambda=0.154 \mathrm{~nm})$. The XRD patterns of Iba and of the BGs after Iba adsorption were were obtained using a MiniFlex II XRD system from Rigaku Co. (Tokyo, Japan), with CuK $\alpha$ radiation $(\lambda=0.154 \mathrm{~nm})$ in the angle $2 \theta$ range from 5 to $80^{\circ}$.

The pore properties of the BGs were determined by the nitrogen adsorption/desorption measurements at $77 \mathrm{~K}$ using a volumetric gas adsorption analyser (AUTOSORB-1-MP, Quantachrome Instruments, Boynton Beach, FL, USA). Prior to measurement, the samples were appropriately outgassed (at $250^{\circ} \mathrm{C}$ for $12 \mathrm{~h}$ ) under ultra-high vacuum $\left(10^{-6} \mathrm{mbar}\right)$, while ultra-pure $\mathrm{N}_{2}$ was used. 
The BET area values were calculated by the Brunauer-Emmett-Teller (BET) method, following the BET consistency criteria. Pore size distributions were deduced by fitting the adsorption isotherms based on a non-local density functional theory (NLDFT) kernel developed for $\mathrm{N}_{2}$ at $77 \mathrm{~K}$ on silica materials with cylindrical pores.

Thermogravimetric analysis, before and after the adsorption of Iba, was carried out with a Setsys16/18 TG-DTA system (Setaram Instrumentation, Caluire, France). Samples were placed in alumina crucibles and heated from ambient temperature to $800{ }^{\circ} \mathrm{C}$ at $20^{\circ} \mathrm{C} / \mathrm{min}$ using a $50 \mathrm{~mL} / \mathrm{min}$ flow of $\mathrm{N}_{2}$; an empty alumina crucible was used as reference.

The in vitro bioactivity of the BGs was assessed by monitoring the formation of an apatite layer on the surface of the synthesized glasses that were immersed in a simulated body fluid (SBF) solution buffered at $\mathrm{pH} 7.4$ [117]. The samples were soaked in SBF in a concentration of $1.5 \mathrm{mg} / \mathrm{mL}$ and incubated in closed falcon tubes at $37^{\circ} \mathrm{C}$ for $1,3,7$ and 14 days. The falcon tubes were placed inside a shaking incubator (LSI-3016R, Labtech, Heathfield, United Kingdom) at a fixed temperature of $37^{\circ} \mathrm{C}$ and speed $200 \mathrm{rpm}$. At the selected time points, the powders were separated from the SBF solution by centrifugation at $5000 \mathrm{rpm}$ for $5 \mathrm{~min}$, rinsed with acetone to cease further reactions, air dried at room temperature and analyzed using FTIR and XRD (Rigaku R-Axis IV) to detect the HA phase formation.

\subsubsection{Characterization of the Composite Films}

The morphology of the PCL composite films was examined using a JEOL JMS-840A scanning electron microscope (SEM) equipped with an energy-dispersive X-ray Oxford ISIS 300 microanalytical system (Oxford Instruments). All samples were coated with carbon black to avoid charging under the electron beam.

FTIR spectra of the thin films were obtained using a Perkin-Elmer FTIR spectrometer (Waltham MA, USA), model Spectrum One in absorbance mode and in the spectral region of $400-4.000 \mathrm{~cm}^{-1}$ using a resolution of $4 \mathrm{~cm}^{-1}$ and 64 co-added scans.

Differential scanning calorimetry (DSC) measurements were performed with a Pyris-6 instrument (Perkin Elmer, Waltham, MA, USA) calibrated with Indium and Zinc standards, under $\mathrm{N}_{2}$ flow. For each measurement, 5-10 mg of each sample was placed in a sealed aluminum pan and heated from ambient temperature to $100^{\circ} \mathrm{C}$ with a heating rate of $10^{\circ} \mathrm{C} / \mathrm{min}$, and subsequently cooled to $10^{\circ} \mathrm{C}$ with a cooling rate of $5^{\circ} \mathrm{C} / \mathrm{min}$. The degree of crystallinity $\mathrm{X}_{\mathrm{c}}(\%)$ was calculated with the equation:

$$
\mathrm{X}_{\mathrm{c}}=\Delta \mathrm{H}_{\mathrm{m}} /(1-\mathrm{x}) \Delta \mathrm{H}^{0} \mathrm{~m} \%
$$

where $\Delta \mathrm{H}_{\mathrm{m}}$ is the melting enthalpy, $\mathrm{x}$ is the weight fraction of the BG particles and $\Delta \mathrm{H}^{0} \mathrm{~m}$ the theoretical heat of fusion for 100\% crystalline PCL, $135 \mathrm{~J} / \mathrm{g}$ [118].

Thermogravimetric analysis was carried out with a Setsys16/18 TG-DTA system (Setaram Instrumentation, Caluire, France). Samples were placed in alumina crucibles and heated from ambient temperature to $620^{\circ} \mathrm{C}$ at $20^{\circ} \mathrm{C} / \mathrm{min}$ using a $50 \mathrm{~mL} / \mathrm{min}$ flow of $\mathrm{N}_{2}$; an empty alumina crucible was used as reference.

The materials under study were assessed through nanoindentation tests in order to compare their modulus and hardness. In instrumented indentation tests the load is measured as a function of penetration depth. Such tests enable local variations of modulus and hardness to be measured precisely [119-122]. In the current work the indentations were conducted using a dynamic ultra-micro-hardness tester (DUH-211; Shimadzu Co., Kyoto, Japan) fitted with a triangular pyramid indenter tip (Berkovich indenter). The indentations made on the surface of the nanocomposites under study appeared as an equilateral triangle. Ten measurements were conducted on each specimen, which were purposely scattered on the surface. After contact of the indenter with the surface, this was driven into the surface until a peak load of $10 \mathrm{mN}$ was reached. The peak load was held for $3 \mathrm{~s}$ (in order to minimize the effect of viscoelastic deformation of the specimen, notably creep, on property 
measurements) and then the indenter was unloaded, to a load of zero. The statistical significance was analyzed by Student's t-test. A $p$-value $<0.05$ was considered as statistically significant.

The apparent contact angle of water was measured on a contact angle analyzer (Kruss EasyDrop Standard, Hamburg, Germany), by gently placing a water droplet $(5 \mu \mathrm{L})$ on the surface of the polymeric films. The presented values were averaged over at least three points for each sample, using the circle fitting method. The statistical significance was analyzed by Student's t-test. A $p$-value $<0.05$ was considered as statistically significant.

For the in vitro biomineralization experiments, the nanocomposites in the form of films were soaked in SBF, buffered at $\mathrm{pH} 7.4$, and incubated at $37^{\circ} \mathrm{C}$ in closed containers for 14 days. After the immersion test, the films were removed and washed three times with deionized water to remove adsorbed minerals. The films were dried under vacuum and characterized by SEM using the conditions described previously.

An iCAP Q ICP-MS (Thermo Scientific, Fisher Scientific, Ottawa, ON, Canada) equipped with a PFA-ST nebulizer, nickel interface cones and $2.5 \mathrm{~mm}$ quartz injector with Qtegra ${ }^{\mathrm{TM}}$ Intelligent Scientific Data Solution ${ }^{\mathrm{TM}}$ Software was used for the determination of ion concentration ( $\mathrm{Si}, \mathrm{Ca}, \mathrm{P}, \mathrm{Sr}$ ) after soaking of the BGs as well as the composite films in SBF for 30 days. The concentration of the samples in SBF was $60 \mathrm{mg} / \mathrm{mL}$ for the BGs and $0.04 \mathrm{mg} / \mathrm{mL}$ for the membranes. The concentrations of trace elements were measured by ICP-MS with 'in-sample switching' between two operational modes: standard mode and kinetic energy discrimination with $\mathrm{He}$ as the cell gas to reduce polyatomic interferences. Internal standard included $\operatorname{Ir}(10 \mu \mathrm{g} \mathrm{L}-1)$ in $2 \%$ trace analytical grade (TAG) $\mathrm{HNO}_{3}$. Multi-element solutions as well as single element solutions were diluted as appropriate to create the calibration curves with concentrations of $0.100,1.00,2.00,5.00,10.0,25.0,50.0$ and $100 \mu \mathrm{g} / \mathrm{L}$. A linear regression was confirmed for all selected elements $\left(R^{2}>0.999\right)$. Using ${ }^{193}$ Ir as the internal standard, all samples were analyzed in triplicate, with instrument parameters of 10 sweeps and $10 \mathrm{~ms}$ dwell time for all elements. For QA/QC, blanks $\left(2 \% \mathrm{HNO}_{3}\right)$ and Reference Material (Proficiency testing, SCHEMA) were analyzed immediately after calibrating the instrument and after every 10 samples. All the blank readings were lower than the instrument detection limits, and the element concentrations determined in the reference material were within $10 \%$ of the certified values.

\subsection{Cell Studies}

3.7.1. Isolation, Cultivation and Genetic Modification of Wharton's Jelly-Derived Mesenchymal Stem Cells (WJ-MSCs)

Thirty five $\mathrm{mL}$ of umbilical cord blood were collected with the parents' informed consent in a sterilized box. After a saline wash and a mild cut up with a lancet, an overnight lysis with $4 \mathrm{mg} / \mathrm{mL}$ collagenase, $2 \mathrm{mg} / \mathrm{mL}$ dispase in PBS was performed in a stirring incubator. The next day the mixture was filtered through a $70 \mu \mathrm{m}$ Filter Unit and was subsequently centrifuged at $850 \mathrm{~g}$ for $10 \mathrm{~min}$ at room temperature (RT). The obtained pellet was resuspended in DMEM medium supplemented with $10 \%$ fetal bovine serum (FBS) and 1\% penicillin/streptomycin (DMEM full medium) and was then incubated in culture flasks for $72 \mathrm{~h}$ in a $37{ }^{\circ} \mathrm{C}$ incubator with $5 \% \mathrm{CO}_{2}$. Between the 4th and the 5th passage we performed a Pt2-Venus-neo mediated nucleofection. Approximately $4 \times 10^{5}$ cells were mixed with $7.5 \mu \mathrm{g}$ of plasmid DNA SB100X transposase and pT2-Venus-neo transposon expression plasmids (1:10 ratio) and a subsequent electroporation was performed according to the manufacturer's protocol (Lonzabio, Basel. Switzerland). The cells were then incubated in a well of a 6-well plate in the presence of DMEM full medium until a $90 \%$ confluency after which $100 \mathrm{mg} / \mathrm{mL}$ G418 was added for the selection of the genetically modified WJ-MSCs.

\subsubsection{Sterilization of the Materials and WJ-SCs Plating}

All PCL films were cut into $5 \times 5 \mathrm{~mm}$ pieces and sterilized in gradually reduced ethanol concentrations (100-70-50\%). Next, they were washed three times with $\mathrm{ddH}_{2} \mathrm{O}$ and air dried for $4 \mathrm{~h}$ 
under sterile conditions. Fibrin glue was prepared after blood sampling of a healthy volunteer donor. $15 \mu \mathrm{L}$ of fibrin glue per film were placed in the bottom of a 24-well plate and the materials were seeded from the top using a sterile pincher by applying minimal manual pressure and air dried overnight under sterile conditions. WJ-SCs were detached using Trypsin-EDTA $1 x$ in PBS and were counted in a Neubauer cell counting chamber. $5 \times 10^{4}$ cells/well of each condition were resuspended in DMEM full medium and were subsequently placed above the films. Upon air drying for $4 \mathrm{~h}$ in the incubator, $1 \mathrm{ml}$ DMEM full medium was added per well for the culture initiation either for MTT assay or for osteoinductive differentiation procedure as described below. For the cytotoxicity measurements that performed to CaBG and SrBG samples, NPs were added in the culture supernatants at two different concentrations: 100 and $200 \mathrm{ug} / \mathrm{mL}$ in DMEM. For the sterilization of the solutions, $0.22 \mu \mathrm{m}$ filter units were used. Non-NP treated cells were used as a control group in the same number as the other groups.

\subsubsection{3-[4,5-Dimethylthiazole-2-yl]-2,5-diphenyltetrazolium Bromide (MTT) Assay}

In order to assess the cytotoxicity levels of materials, the MTT assay was performed (Sigma-Aldrich, Saint Louis, MO, USA) $24 \mathrm{~h}$ after the initial cell plating. Briefly, after the medium removal from the wells, MTT reactant was introduced in a ratio of 1:10 in DMEM culture medium and was followed by a $4 \mathrm{~h}$ incubation in $37^{\circ} \mathrm{C}$ with $5 \% \mathrm{CO}_{2}$. Upon the removal of the MTT, $1 \mathrm{~mL} /$ well of DMSO was introduced for one additional hour of incubation in the same conditions. The reduction of MTT was counted at wavelengths 570 and 630 nm (Perkin Elmer).

\subsubsection{Observation under Fluorescence Microscope}

The observation of the cells above the materials was performed under a fluorescence HBO 50 mercury lamp as well as reflectors with fluorescence filter (excitation $488 \mathrm{~nm}$, emission $509 \mathrm{~nm}$ ), while the program for downloading and editing the photos was the Fluorescence Lite software module of AxioVision LE (Carl Zeiss, Oberkochen, Germany).

\subsubsection{Osteogenic Differentiation-Alizarin Red Staining and CPC Quantification}

The induction of differentiation towards bone cells was accomplished by introducing osteogenesis medium, PT-3002 hMSC Osteogenic Differentiation BulletKit (Lonza, Switzerland), in the culture for 28 days. Cells plated in plastic surfaces were used as a control group, in the same number as the rest of the other groups. The successful induction of differentiation towards bone cells was verified with Alizarin Red staining. The quantification of the procedure was carried out with $10 \%$ cetylpyridinium chloride (CPC) in $10 \mathrm{nM}$ sodium phosphate, $\mathrm{pH} 7.0$ for $15 \mathrm{~min}$ in RT. The extracts were 10 times dissolved in 10\% CPC and the Alizarin Red concentration was counted at $562 \mathrm{~nm}$ in a Perkin Elmer spectrometer (Waltham MA, USA).

\subsubsection{Statistical Analysis}

All cell experiments were performed in triplicate and the results were expressed as mean \pm standard deviation. The statistical significance was analyzed by Student's t-test. A $p$-value $<0.05$ was considered as statistically significant.

\subsubsection{Ethical Statement}

This study was approved by the Ethics Committee of Aristotle University of Thessaloniki School of Medicine (390-9/1.7.2017). This research involves Human Participants after their informed consent. Peripheral blood samples were collected from healthy volunteer donors while mesenchymal stromal cells were isolated from Wharton's jelly after parent's approval during stem cell banking in Biohellenika SA Biotechnology Company (Thessaloniki, Greece). 


\section{Conclusions}

Two different mesoporous, sub-micron bioactive glasses with different compositions and large surface areas were prepared with a hydrothermal method. The bioglasses were loaded with ibandronate and used in the preparation of composite thin membranes of poly (e-caprolactone) by the method of spin coating for GBR/GTR applications. The presence of both BGs affected positively the mechanical properties of PCL and its hydrophilicity. The incorporation of $\mathrm{Sr}^{2+}$ ions induces significant bioactivity, which is further enhanced in the presence of ibandronate. All membranes were found to be biocompatible after seeding WJ-MSCs on their surface. WJ-MSCs cultured on PCL-SrBG-Iba sample presented a significant potential for differentiation to osteocytes, suggesting a possible synergistic effect of $\mathrm{Sr}$ and Iba on osteogenesis.

Potential limitations of this study include the inability to quantify the in vitro drug release rate due to its low content and the use of a single method for the estimation of osteogenic differentiation. Further studies are needed to confirm the osteogenic potential of the prepared membranes, quantification of the drug's release rate in different media and finally conducting of in vivo tests to determine if these membranes can be introduced to clinical practice in the future.

Supplementary Materials: The following are available online. Figure S1: DSC thermograms of CaBG-Iba and SrBG-Iba during heating with $20^{\circ} \mathrm{C} / \mathrm{min}$, Figure S2: FT-IR spectra of the composite membranes, Figure S3: DSC thermograms of (a) Iba upon heating, (b) composite thin films upon heating and (c) composite thin films upon cooling, Figure S4: TGA and DTG thermograms of (a-b) PCL/CaBG and (c-d) PCL/SrBG composite thin films, Figure S5. Loading-unloading indentation curves of PCL and its composite films.

Author Contributions: Conceptualization, Z.T.; Investigation, Z.T., D.B. (Diana Baciu), E.G. and D.T.; Supervision, Z.T., D.B. (Dimitrios Bikiaris) and G.C., Writing-original draft, Z.T., D.B. (Diana Baciu) and G.C., Writing-review and editing, Z.T., D.B. (Dimitrios Bikiaris), G.C., T.S.

Funding: D. Baciu gratefully acknowledges the Greek State Scholarship's Foundation (IKY) for the postdoctoral fellowship in the frame of MIS-5001552 Action.

Acknowledgments: Z. Terzopoulou would like to acknowledge Dimitrios Papageorgiou and Oana Istrate of the University of Manchester for the contact angle measurements, as well as Dimitra Lambropoulou and Anna Ofrydopoulou for performing the ICP-MS experiments in Aristotle University of Thessaloniki. D. Baciu gratefully acknowledges Ch. Tampaxis of the HYSORB Lab, Institute of Nanoscience and Nanotechnology, National Center for Scientific Research "Demokritos", for his kind help with $\mathrm{N}_{2}$ adsorption/desorption measurements.

Conflicts of Interest: The authors declare no conflict of interest.

\section{References}

1. Garcia, J.; Dodge, A.; Luepke, P.; Wang, H.-L.; Kapila, Y.; Lin, G.-H. Effect of membrane exposure on guided bone regeneration: A systematic review and meta-analysis. Clin. Oral Implants Res. 2018, 29, 328-338. [CrossRef]

2. Liu, J.; Kerns, D.G. Suppl 1: Mechanisms of guided bone regeneration: A review. Open Dent. J. 2014, 8, 56. [CrossRef]

3. Murphy, K.G.; Gunsolley, J.C. Guided tissue regeneration for the treatment of periodontal intrabony and furcation defects: A systematic review. Ann. Periodontol. 2003, 8, 266-302. [CrossRef]

4. Wang, J.; Wang, L.; Zhou, Z.; Lai, H.; Xu, P.; Liao, L.; Wei, J. Biodegradable polymer membranes applied in guided bone/tissue regeneration: A review. Polymers 2016, 8, 115. [CrossRef]

5. Gentile, P.; Chiono, V.; Tonda-turo, C.; Ferreira, A.M.; Ciardelli, G. Polymeric membranes for guided bone regeneration. Biotechnol. J. 2011, 6, 1187-1197. [CrossRef]

6. Tempro, P.J.; Nalbandian, J. Colonization of retrieved polytetrafluoroethylene membranes: Morphological and microbiological observations. J. Periodontol. 1993, 64, 162-168. [CrossRef]

7. Mondal, D.; Griffith, M.; Venkatraman, S.S. Polycaprolactone-based biomaterials for tissue engineering and drug delivery: Current scenario and challenges. Int. J. Polym. Mater. Polym. Biomater. 2016, 65, 255-265. [CrossRef]

8. Lee, E.J.; Teng, S.H.; Jang, T.S.; Wang, P.; Yook, S.W.; Kim, H.E.; Koh, Y.H. Nanostructured poly( $\varepsilon$-caprolactone)-silica xerogel fibrous membrane for guided bone regeneration. Acta Biomater. 2010, 6, 3557-3565. [CrossRef] 
9. Ji, W.; Yang, F.; Ma, J.; Bouma, M.J.; Boerman, O.C.; Chen, Z.; van den Beucken, J.J.J.P.; Jansen, J.A. Incorporation of stromal cell-derived factor- $1 \alpha$ in PCL/gelatin electrospun membranes for guided bone regeneration. Biomaterials 2013, 34, 735-745. [CrossRef] [PubMed]

10. Wan, J.C.; Jun, H.K.; Se, H.O.; Hyun, H.N.; Jin, M.K.; Lee, J.H. Hydrophilized polycaprolactone nanofiber mesh-embedded poly(glycolic-co- lactic acid) membrane for effective guided bone regeneration. J. Biomed. Mater. Res. Part A 2009, 91, 400-407.

11. Fujihara, K.; Kotaki, M.; Ramakrishna, S. Guided bone regeneration membrane made of polycaprolactone/calcium carbonate composite nano-fibers. Biomaterials 2005, 26, 4139-4147. [CrossRef] [PubMed]

12. Won, J.Y.; Park, C.Y.; Bae, J.H.; Ahn, G.; Kim, C.; Lim, D.H.; Cho, D.W.; Yun, W.S.; Shim, J.H.; Huh, J.B. Evaluation of 3D printed PCL/PLGA/ $\beta$-TCP versus collagen membranes for guided bone regeneration in a beagle implant model. Biomed. Mater. 2016, 11. [CrossRef] [PubMed]

13. Ren, K.; Wang, Y.; Sun, T.; Yue, W.; Zhang, H. Electrospun PCL/gelatin composite nanofiber structures for effective guided bone regeneration membranes. Mater. Sci. Eng. C 2017, 78, 324-332. [CrossRef]

14. Shim, J.H.; Won, J.Y.; Park, J.H.; Bae, J.H.; Ahn, G.; Kim, C.H.; Lim, D.H.; Cho, D.W.; Yun, W.S.; Bae, E.B.; et al. Effects of 3D-printed polycaprolactone/ $\beta$-tricalcium phosphate membranes on guided bone regeneration. Int. J. Mol. Sci. 2017, 18, 899. [CrossRef] [PubMed]

15. Pitaluga, L.H.; Souza, M.T.; Zanotto, E.D.; Romero, M.E.S.; Hatton, P.V. Electrospun F18 bioactive glass/PCL-poly ( $\varepsilon$-caprolactone)-membrane for guided tissue regeneration. Materials 2018, 11, 400. [CrossRef] [PubMed]

16. Zhang, Q.; Lv, S.; Lu, J.; Jiang, S.; Lin, L. Characterization of polycaprolactone/collagen fibrous scaffolds by electrospinning and their bioactivity. Int. J. Biol. Macromol. 2015, 76, 94-101. [CrossRef] [PubMed]

17. Shim, J.-H.; Huh, J.-B.; Park, J.Y.; Jeon, Y.-C.; Kang, S.S.; Kim, J.Y.; Rhie, J.-W.; Cho, D.-W. Fabrication of blended polycaprolactone/poly (lactic-Co-glycolic acid)/ $\beta$-tricalcium phosphate thin membrane using solid freeform fabrication technology for guided bone regeneration. Tissue Eng. Part A 2012, 19, 317-328. [CrossRef]

18. Chakraborti, M.; Jackson, J.K.; Plackett, D.; Brunette, D.M.; Burt, H.M. Drug intercalation in layered double hydroxide clay: Application in the development of a nanocomposite film for guided tissue regeneration. Int. J. Pharm. 2011, 416, 305-313. [CrossRef]

19. Rowe, M.J.; Kamocki, K.; Pankajakshan, D.; Li, D.; Bruzzaniti, A.; Thomas, V.; Blanchard, S.B.; Bottino, M.C. Dimensionally stable and bioactive membrane for guided bone regeneration: An in vitro study. J. Biomed. Mater. Res. Part B Appl. Biomater. 2016, 104, 594-605. [CrossRef]

20. Yang, F.; Both, S.K.; Yang, X.; Walboomers, X.F.; Jansen, J.A. Development of an electrospun nano-apatite/PCL composite membrane for GTR/GBR application. Acta Biomater. 2009, 5, 3295-3304. [CrossRef]

21. Castro, A.G.B.; Diba, M.; Kersten, M.; Jansen, J.A.; van den Beucken, J.J.J.P.; Yang, F. Development of a PCL-silica nanoparticles composite membrane for guided bone regeneration. Mater. Sci. Eng. C 2018, 85, 154-161. [CrossRef] [PubMed]

22. Lee, H.H.; Yu, H.S.; Jang, J.H.; Kim, H.W. Bioactivity improvement of poly( $\varepsilon$-caprolactone) membrane with the addition of nanofibrous bioactive glass. Acta Biomater. 2008, 4, 622-629. [CrossRef] [PubMed]

23. Leal, A.I.; Caridade, S.G.; Ma, J.; Yu, N.; Gomes, M.E.; Reis, R.L.; Jansen, J.A.; Walboomers, X.F.; Mano, J.F. Asymmetric PDLLA membranes containing bioglass ${ }^{\circledR}$ for guided tissue regeneration: Characterization and in vitro biological behavior. Dent. Mater. 2013, 29, 427-436. [CrossRef] [PubMed]

24. Mota, J.; Yu, N.; Caridade, S.G.; Luz, G.M.; Gomes, M.E.; Reis, R.L.; Jansen, J.A.; Frank Walboomers, X.; Mano, J.F. Chitosan/bioactive glass nanoparticle composite membranes for periodontal regeneration. Acta Biomater. 2012, 8, 4173-4180. [CrossRef] [PubMed]

25. Zhao, X.; Wu, Y.; Du, Y.; Chen, X.; Lei, B.; Xue, Y.; Ma, P.X. A highly bioactive and biodegradable poly(glycerol sebacate)-silica glass hybrid elastomer with tailored mechanical properties for bone tissue regeneration. J. Mater. Chem. B 2015, 3, 3222-3233. [CrossRef]

26. Pazarçeviren, A.E.; Evis, Z.; Keskin, D.; Tezcaner, A. Resorbable PCEC/gelatin-bismuth doped bioglass-graphene oxide bilayer membranes for guided bone regeneration. Biomed. Mater. 2019. [CrossRef]

27. Fernandes, J.S.; Gentile, P.; Martins, M.; Neves, N.M.; Miller, C.; Crawford, A.; Pires, R.A.; Hatton, P.; Reis, R.L. Reinforcement of poly-L-lactic acid electrospun membranes with strontium borosilicate bioactive glasses for bone tissue engineering. Acta Biomater. 2016, 44, 168-177. [CrossRef] 
28. Dehnavi, S.S.; Mehdikhani, M.; Rafienia, M.; Bonakdar, S. Preparation and in vitro evaluation of polycaprolactone/PEG/bioactive glass nanopowders nanocomposite membranes for GTR/GBR applications. Mater. Sci. Eng. C 2018, 90, 236-247. [CrossRef] [PubMed]

29. Li, W.; Ding, Y.; Yu, S.; Yao, Q.; Boccaccini, A.R. Multifunctional chitosan-45S5 bioactive glass-poly(3-hydroxybutyrate-co-3-hydroxyvalerate) microsphere composite membranes for guided tissue/bone regeneration. ACS Appl. Mater. Interfaces 2015, 7, 20845-20854. [CrossRef] [PubMed]

30. Caridade, S.G.; Merino, E.G.; Martins, G.V.; Luz, G.M.; Alves, N.M.; Mano, J.F. Membranes of poly(dl-lactic acid)/bioglass ${ }^{\circledR}$ with asymmetric bioactivity for biomedical applications. J. Bioact. Compat. Polym. 2012, 27, 429-440. [CrossRef]

31. Venkatesan, J.; Kim, S.-K. Nano-hydroxyapatite composite biomaterials for bone tissue engineering-a review. J. Biomed. Nanotechnol. 2014, 10, 3124-3140. [CrossRef] [PubMed]

32. Sahoo, N.G.; Pan, Y.Z.; Li, L.; He, C. Bin Nanocomposites for bone tissue regeneration. Nanomedicine 2013, 8, 639-653. [CrossRef] [PubMed]

33. Bramhill, J.; Ross, S.; Ross, G. Bioactive nanocomposites for tissue repair and regeneration: A review. Int. J. Environ. Res. Public Health 2017, 14, 66. [CrossRef] [PubMed]

34. Boccaccini, A.R.; Erol, M.; Stark, W.J.; Mohn, D.; Hong, Z.; Mano, J.F. Polymer/bioactive glass nanocomposites for biomedical applications: A review. Compos. Sci. Technol. 2010, 70, 1764-1776. [CrossRef]

35. Boccaccini, A.R.; Blaker, J.J. Bioactive composite materials for tissue engineering scaffolds. Expert Rev. Med. Devices 2005, 2, 303-317. [CrossRef] [PubMed]

36. Novoselov, K.S.; Geim, A.K.; Morozov, S.V.; Jiang, D.; Zhang, Y.; Dubonos, S.V.; Grigorieva, I.V.; Firsov, A.A. Electric field effect in atomically thin carbon films. Science 2004, 306, 666-669. [CrossRef] [PubMed]

37. Thormann, U.; Ray, S.; Sommer, U.; ElKhassawna, T.; Rehling, T.; Hundgeburth, M.; Henß, A.; Rohnke, M.; Janek, J.; Lips, K.S.; et al. Bone formation induced by strontium modified calcium phosphate cement in critical-size metaphyseal fracture defects in ovariectomized rats. Biomaterials 2013, 34, 8589-8598. [CrossRef]

38. Huang, J. Chapter 20-design and development of ceramics and glasses. In Biology and Engineering of Stem Cell Niches 2017; Vishwakarma, A., Karp, J.M., Eds.; Academic Press: Boston, MA, USA, 2017; pp. 315-329.

39. Kargozar, S.; Montazerian, M.; Hamzehlou, S.; Kim, H.W.; Baino, F. Mesoporous bioactive glasses: Promising platforms for antibacterial strategies. Acta Biomater. 2018, 81, 1-19. [CrossRef]

40. Shahin-Shamsabadi, A.; Hashemi, A.; Tahriri, M.; Bastami, F.; Salehi, M.; Mashhadi Abbas, F. Mechanical, material, and biological study of a PCL/bioactive glass bone scaffold: Importance of viscoelasticity. Mater. Sci. Eng. C 2018, 90, 280-288. [CrossRef]

41. Mouriño, V.; Vidotto, R.; Cattalini, J.P.; Boccaccini, A.R. Enhancing biological activity of bioactive glass scaffolds by inorganic ion delivery for bone tissue engineering. Curr. Opin. Biomed. Eng. 2019, 10, $23-34$. [CrossRef]

42. Lakhkar, N.J.; Lee, I.-H.; Kim, H.-W.; Salih, V.; Wall, I.B.; Knowles, J.C. Bone formation controlled by biologically relevant inorganic ions: Role and controlled delivery from phosphate-based glasses. Adv. Drug Deliv. Rev. 2013, 65, 405-420. [CrossRef] [PubMed]

43. Rabiee, S.M.; Nazparvar, N.; Azizian, M.; Vashaee, D.; Tayebi, L. Effect of ion substitution on properties of bioactive glasses: A review. Ceram. Int. 2015, 41, 7241-7251. [CrossRef]

44. Gentleman, E.; Fredholm, Y.C.; Jell, G.; Lotfibakhshaiesh, N.; O’Donnell, M.D.; Hill, R.G.; Stevens, M.M. The effects of strontium-substituted bioactive glasses on osteoblasts and osteoclasts in vitro. Biomaterials 2010, 31, 3949-3956. [CrossRef] [PubMed]

45. Du, J.; Xiang, Y. Effect of strontium substitution on the structure, ionic diffusion and dynamic properties of 45S5 bioactive glasses. J. Non. Cryst. Solids 2012, 358, 1059-1071. [CrossRef]

46. Hoppe, A.; Güldal, N.S.; Boccaccini, A.R. A review of the biological response to ionic dissolution products from bioactive glasses and glass-ceramics. Biomaterials 2011, 32, 2757-2774. [CrossRef]

47. Yang, F.; Yang, D.; Tu, J.; Zheng, Q.; Cai, L.; Wang, L. Strontium enhances osteogenic differentiation of mesenchymal stem cells and in vivo bone formation by activating Wnt/catenin signaling. Stem Cells 2011, 29, 981-991. [CrossRef]

48. Kumar, S.; Chatterjee, K. Strontium eluting graphene hybrid nanoparticles augment osteogenesis in a 3D tissue scaffold. Nanoscale 2015, 7, 2023-2033. [CrossRef] 
49. Peng, S.; Zhou, G.; Luk, K.D.K.; Cheung, K.M.C.; Li, Z.; Lam, W.M.; Zhou, Z.; Lu, W.W. Strontium promotes osteogenic differentiation of mesenchymal stem cells through the Ras/MAPK signaling pathway. Cell. Physiol. Biochem. 2009, 23, 165-174. [CrossRef]

50. Aimaiti, A.; Maimaitiyiming, A.; Boyong, X.; Aji, K.; Li, C.; Cui, L. Low-dose strontium stimulates osteogenesis but high-dose doses cause apoptosis in human adipose-derived stem cells via regulation of the ERK1/2 signaling pathway. Stem Cell Res. Ther. 2017, 8, 282. [CrossRef]

51. Denry, I.; Goudouri, O.-M.; Fredericks, D.C.; Akkouch, A.; Acevedo, M.R.; Holloway, J.A. Strontium-releasing fluorapatite glass-ceramic scaffolds: Structural characterization and in vivo performance. Acta Biomater. 2018, 75, 463-471. [CrossRef]

52. Zhang, H.; Moriyama, Y.; Ayukawa, Y.; Rakhmatia, Y.D.; Tomita, Y.; Yasunami, N.; Koyano, K. Generation and histomorphometric evaluation of a novel fluvastatin-containing poly(lactic-co-glycolic acid) membrane for guided bone regeneration. Odontology 2019, 107, 37-45. [CrossRef] [PubMed]

53. Caballé-Serrano, J.; Abdeslam-Mohamed, Y.; Munar-Frau, A.; Fujioka-Kobayashi, M.; Hernández-Alfaro, F.; Miron, R. Adsorption and release kinetics of growth factors on barrier membranes for guided tissue/bone regeneration: A systematic review. Arch. Oral Biol. 2019, 100, 57-68. [CrossRef] [PubMed]

54. Hum, J.; Boccaccini, A.R. Bioactive glasses as carriers for bioactive molecules and therapeutic drugs: A review. J. Mater. Sci. Mater. Med. 2012, 23, 2317-2333. [CrossRef] [PubMed]

55. Baino, F.; Hamzehlou, S.; Kargozar, S. Bioactive glasses: Where are we and where are we going? J. Funct. Biomater. 2018, 9, 25. [CrossRef] [PubMed]

56. Diba, M.; Camargo, W.A.; Zinkevich, T.; Grünewald, A.; Detsch, R.; Kabiri, Y.; Kentgens, A.P.M.; Boccaccini, A.R.; van den Beucken, J.J.J.P.; Leeuwenburgh, S.C.G. Hybrid particles derived from alendronate and bioactive glass for treatment of osteoporotic bone defects. J. Mater. Chem. B 2019, 7, 796-808. [CrossRef]

57. Rosenqvist, K.; Airaksinen, S.; Fraser, S.J.; Gordon, K.C.; Juppo, A.M. Interaction of bioactive glass with clodronate. Int. J. Pharm. 2013, 452, 102-107. [CrossRef] [PubMed]

58. Kim, S.E.; Yun, Y.P.; Shim, K.S.; Kim, H.J.; Park, K.; Song, H.R. 3D printed alendronate-releasing poly(caprolactone) porous scaffolds enhance osteogenic differentiation and bone formation in rat tibial defects. Biomed. Mater. 2016, 11. [CrossRef] [PubMed]

59. Ezra, A.; Golomb, G. Administration routes and delivery systems of bisphosphonates for the treatment of bone resorption. Adv. Drug Deliv. Rev. 2000, 42, 175-195. [CrossRef]

60. Fleish, H. Bisphosphonates. Drugs 1991, 42, 919-944. [CrossRef]

61. Kim, H.K.; Kim, J.H.; Abbas, A.A.; Yoon, T.R. Alendronate enhances osteogenic differentiation of bone marrow stromal cells: A preliminary study. Clin. Orthop. Relat. Res. 2009, 467, 3121-3128. [CrossRef]

62. Long, K.A.; Jackson, J.K.; Yang, C.; Chehroudi, B.; Brunette, D.M.; Burt, H.M. Controlled release of alendronate from polymeric films. J. Biomater. Sci. Polym. Ed. 2009, 20, 653-672. [CrossRef] [PubMed]

63. Terzopoulou, Z.; Baciu, D.; Gounari, E.; Steriotis, T.; Charalambopoulou, G.; Bikiaris, D. Biocompatible nanobioglass reinforced poly( $\varepsilon$-caprolactone) composites synthesized via in situ ring opening polymerization. Polymers 2018, 10, 381. [CrossRef] [PubMed]

64. Xu, L.; Yamamoto, A. Characteristics and cytocompatibility of biodegradable polymer film on magnesium by spin coating. Colloid. Surface. B 2012, 93, 67-74. [CrossRef] [PubMed]

65. Kim, Y.K.; Lee, K.B.; Kim, S.Y.; Jang, Y.S.; Kim, J.H.; Lee, M.H. Improvement of osteogenesis by a uniform PCL coating on a magnesium screw for biodegradable applications. Sci. Rep. 2018, 8, 1-11. [CrossRef] [PubMed]

66. Chlanda, A.; Oberbek, P.; Heljak, M.; Kijeńska-Gawrońska, E.; Bolek, T.; Gloc, M.; John, Ł.; Janeta, M.; Woźniak, M.J. Fabrication, multi-scale characterization and in-vitro evaluation of porous hybrid bioactive glass polymer-coated scaffolds for bone tissue engineering. Mater. Sci. Eng. C 2019, 94, 516-523. [CrossRef]

67. Alani, A.; Knowles, J.C.; Chrzanowski, W.; Ng, Y.L.; Gulabivala, K. Ion release characteristics, precipitate formation and sealing ability of a phosphate glass-polycaprolactone-based composite for use as a root canal obturation material. Dent. Mater. 2009, 25, 400-410. [CrossRef]

68. Wong, H.M.; Yeung, K.W.K.; Lam, K.O.; Tam, V.; Chu, P.K.; Luk, K.D.K.; Cheung, K.M.C. A biodegradable polymer-based coating to control the performance of magnesium alloy orthopaedic implants. Biomaterials 2010, 31, 2084-2096. [CrossRef]

69. Zhou, Z.; Cunningham, E.; Lennon, A.; McCarthy, H.O.; Buchanan, F.; Clarke, S.A.; Dunne, N. Effects of poly ( $\varepsilon$-caprolactone) coating on the properties of three-dimensional printed porous structures. J. Mech. Behav. Biomed. Mater. 2017, 70, 68-83. [CrossRef] 
70. Fiedler, T.; Videira, A.C.; Bártolo, P.; Strauch, M.; Murch, G.E.; Ferreira, J.M.F. On the mechanical properties of PLC-bioactive glass scaffolds fabricated via BioExtrusion. Mater. Sci. Eng. C 2015, 57, 288-293. [CrossRef]

71. Mourão, H.A.J.L.; Lopes, O.F.; Ribeiro, C.; Mastelaro, V.R. Rapid hydrothermal synthesis and pH-dependent photocatalysis of strontium titanate microspheres. Mater. Sci. Semicond. Process. 2015, 30, 651-657. [CrossRef]

72. Yun, H.; Kim, S.; Lee, S.; Song, I. Synthesis of high surface area mesoporous bioactive glass nanospheres. Mater. Lett. 2010, 64, 1850-1853. [CrossRef]

73. Khamsehashari, N.; Hassanzadeh-Tabrizi, S.A.; Bigham, A. Effects of strontium adding on the drug delivery behavior of silica nanoparticles synthesized by P123-assisted sol-gel method. Mater. Chem. Phys. 2018, 205, 283-291. [CrossRef]

74. Saravanapavan, P.; Hench, L.L. Mesoporous calcium silicate glasses. I. Synthesis. J. Non. Cryst. Solids 2003, 318, 1-13. [CrossRef]

75. Moghanian, A.; Firoozi, S.; Tahriri, M. Characterization, in vitro bioactivity and biological studies of sol-gel synthesized SrO substituted $58 \mathrm{~S}$ bioactive glass. Ceram. Int. 2017, 43, 14880-14890. [CrossRef]

76. Bizari, D.; Rabiee, M.; Moztarzadeh, F.; Tahriri, M.; Alavi, S.H.; Masaeli, R. Synthesis, characterization and biological evaluation of sol-gel derived nanomaterial in the ternary system $64 \% \mathrm{SiO}_{2}-31 \% \mathrm{CaO}-5 \% \mathrm{P}_{2} \mathrm{O}_{5}$ as a bioactive glass: In vitro study. Ceram.-Silikaty 2013, 57, 201-209.

77. Luz, G.M.; Mano, J.F. Preparation and characterization of bioactive glass nanoparticles prepared by sol-gel for biomedical applications. Nanotechnology 2011, 22. [CrossRef]

78. Łączka, M.; Cholewa-Kowalska, K.; Osyczka, A.M. Bioactivity and osteoinductivity of glasses and glassceramics and their material determinants. Ceram. Int. 2016, 42, 14313-14325. [CrossRef]

79. Zhang, X.; Zeng, D.; Li, N.; Wen, J.; Jiang, X.; Liu, C.; Li, Y. Functionalized mesoporous bioactive glass scaffolds for enhanced bone tissue regeneration. Sci. Rep. 2016, 6, 19361. [CrossRef]

80. Fujikura, K.; Karpukhina, N.; Kasuga, T.; Brauer, D.S.; Hill, R.G.; Law, R.V. Influence of strontium substitution on structure and crystallisation of Bioglass®45S5. J. Mater. Chem. 2012, 22, 7395-7402. [CrossRef]

81. Taherkhani, S.; Moztarzadeh, F. Influence of strontium on the structure and biological properties of sol-gel-derived mesoporous bioactive glass (MBG) powder. J. Sol-Gel Sci. Technol. 2016, 78, 539-549. [CrossRef]

82. Suzuki, K.; Ikari, K.; Imai, H. Synthesis of silica nanoparticles having a well-ordered mesostructure using a double surfactant system. J. Am. Chem. Soc. 2004, 126, 462-463. [CrossRef] [PubMed]

83. Chen, B.; Wang, Z.; Quan, G.; Peng, X.; Pan, X.; Wang, R.; Xu, Y.; Li, G.; Wu, C. In vitro and in vivo evaluation of ordered mesoporous silica as a novel adsorbent in liquisolid formulation. Int. J. Nanomedicine 2012, 7, 199. [PubMed]

84. Tian, L.; Peng, C.; Shi, Y.; Guo, X.; Zhong, B.; Qi, J.; Wang, G.; Cai, Q.; Cui, F. Effect of mesoporous silica nanoparticles on dentinal tubule occlusion: An in vitro study using SEM and image analysis. Dent. Mater. J. 2014, 33, 125-132. [CrossRef] [PubMed]

85. Wu, C.; Chang, J. Mesoporous bioactive glasses: Structure characteristics, drug/growth factor delivery and bone regeneration application. Interface Focus 2012, 2, 292-306. [CrossRef] [PubMed]

86. Li, X.; Shi, J.; Dong, X.; Zhang, L.; Zeng, H. A mesoporous bioactive glass/polycaprolactone composite scaffold and its bioactivity behavior. J. Biomed. Mater. Res. Part A 2008, 84, 84-91. [CrossRef] [PubMed]

87. Izquierdo-Barba, I.; Vallet-Regí, M. Mesoporous bioactive glasses: Relevance of their porous structure compared to that of classical bioglasses. Biomed. Glas. 2015. [CrossRef]

88. Fiorilli, S.; Molino, G.; Pontremoli, C.; Iviglia, G.; Torre, E.; Cassinelli, C.; Morra, M.; Vitale-Brovarone, C. The incorporation of strontium to improve bone-regeneration ability of mesoporous bioactive glasses. Materials 2018, 11, 678. [CrossRef]

89. Hu, Q.; Jiang, W.; Chen, X.; Li, Y.; Liang, Q. The effects of Sr concentration on physicochemical properties, bioactivity and biocompatibility of sub-micron bioactive glasses spheres. Adv. Powder Technol. 2017, 28, 2713-2722. [CrossRef]

90. Shahrabi, S.; Hesaraki, S.; Moemeni, S.; Khorami, M. Structural discrepancies and in vitro nanoapatite formation ability of sol-gel derived glasses doped with different bone stimulator ions. Ceram. Int. 2011, 37, 2737-2746. [CrossRef]

91. Wu, C.; Chang, J.; Xiao, Y. Mesoporous bioactive glasses as drug delivery and bone tissue regeneration platforms. Ther. Deliv. 2011, 2, 1189-1198. [CrossRef] 
92. Srisubut, S.; Teerakapong, A.; Vattraphodes, T.; Taweechaisupapong, S. Effect of local delivery of alendronate on bone formation in bioactive glass grafting in rats. Oral Surg. Oral Med. Oral Pathol. Oral Radiol. Endodontology 2007, 104, 11-16. [CrossRef] [PubMed]

93. Wang, X.; Zeng, D.; Weng, W.; Huang, Q.; Zhang, X.; Wen, J.; Wu, J.; Jiang, X. Alendronate delivery on amino modified mesoporous bioactive glass scaffolds to enhance bone regeneration in osteoporosis rats. Artif. Cells Nanomed. Biotechnol. 2018, 46, 171-181. [CrossRef] [PubMed]

94. Miladi, K.; Sfar, S.; Fessi, H.; Elaissari, A. Enhancement of alendronate encapsulation in chitosan nanoparticles. J. Drug Deliv. Sci. Technol. 2015, 30, 391-396. [CrossRef]

95. López-Noriega, A.; Arcos, D.; Vallet-Regí, M. Functionalizing mesoporous bioglasses for long-term anti-osteoporotic drug delivery. Chem. A Eur. J. 2010, 16, 10879-10886. [CrossRef] [PubMed]

96. Ventimiglia, G.; Magrone, D.; Castaldi, G. Polymorphic Forms of Ibandronate Sodium and Processes for Preparation Thereof. International Patent Application No. PCT/EP2008/064401, 30 April 2009.

97. Simon, D.; Holland, A.; Shanks, R. Poly (caprolactone) thin film preparation, morphology, and surface texture. J. Appl. Polym. Sci. 2007, 103, 1287-1294. [CrossRef]

98. Mattioli-Belmonte, M.; Vozzi, G.; Whulanza, Y.; Seggiani, M.; Fantauzzi, V.; Orsini, G.; Ahluwalia, A. Tuning polycaprolactone-carbon nanotube composites for bone tissue engineering scaffolds. Mater. Sci. Eng. C 2012, 32, 152-159. [CrossRef]

99. Degner, J.; Singer, F.; Cordero, L.; Boccaccini, A.R.; Virtanen, S. Electrochemical investigations of magnesium in DMEM with biodegradable polycaprolactone coating as corrosion barrier. Appl. Surf. Sci. 2013, 282, 264-270. [CrossRef]

100. Dziadek, M.; Zagrajczuk, B.; Ziabka, M.; Dziadek, K.; Cholewa-Kowalska, K. The role of solvent type, size and chemical composition of bioactive glass particles in modulating material properties of poly( $\varepsilon$-caprolactone) based composites. Compos. Part A Appl. Sci. Manuf. 2016, 90, 90-99. [CrossRef]

101. Terzopoulou, Z.; Papageorgiou, D.G.; Papageorgiou, G.Z.; Bikiaris, D.N. Effect of surface functionalization of halloysite nanotubes on synthesis and thermal properties of poly(E-caprolactone). J. Mater. Sci. 2018, 53, 6519-6541. [CrossRef]

102. Allo, B.A.; Rizkalla, A.S.; Mequanint, K. Synthesis and electrospinning of $\varepsilon$-polycaprolactone-bioactive glass hybrid biomaterials via a sol-gel process. Langmuir 2010, 26, 18340-18348. [CrossRef]

103. Larrañaga, A.; Sarasua, J.-R. Effect of bioactive glass particles on the thermal degradation behaviour of medical polyesters. Polym. Degrad. Stab. 2013, 98, 751-758. [CrossRef]

104. Diamanti, E.; Sarasua, J.R. Effects of bioactive glass particles on the mechanical and thermal behavior of poly (E-caprolactone). Macromol. Symp. 2012, 321-322, 25-29. [CrossRef]

105. Larrañaga, A.; Petisco, S.; Sarasua, J.R. Improvement of thermal stability and mechanical properties of medical polyester composites by plasma surface modification of the bioactive glass particles. Polym. Degrad. Stab. 2013, 98, 1717-1723. [CrossRef]

106. Dziadek, M.; Pawlik, J.; Menaszek, E.; Stodolak-Zych, E.; Cholewa-Kowalska, K. Effect of the preparation methods on architecture, crystallinity, hydrolytic degradation, bioactivity, and biocompatibility of PCL/bioglass composite scaffolds. J. Biomed. Mater. Res. Part B Appl. Biomater. 2015, 103, 1580-1593. [CrossRef]

107. Poh, P.S.P.; Hutmacher, D.W.; Stevens, M.M.; Woodruff, M.A. Fabrication and in vitro characterization of bioactive glass composite scaffolds for bone regeneration. Biofabrication 2013, 5. [CrossRef]

108. Goel, A.; Rajagopal, R.R.; Ferreira, J.M.F. Influence of strontium on structure, sintering and biodegradation behaviour of $\mathrm{CaO}-\mathrm{MgO}-\mathrm{SrO}-\mathrm{SiO}_{2}-\mathrm{P}_{2} \mathrm{O}_{5}-\mathrm{CaF}_{2}$ glasses. Acta Biomater. 2011, 7, 4071-4080. [CrossRef]

109. Bang, L.T.; Ramesh, S.; Purbolaksono, J.; Ching, Y.C.; Long, B.D.; Chandran, H.; Othman, R. Effects of silicate and carbonate substitution on the properties of hydroxyapatite prepared by aqueous co-precipitation method. Mater. Des. 2015, 87, 788-796. [CrossRef]

110. Lao, J.; Jallot, E.; Nedelec, J.-M. Strontium-delivering glasses with enhanced bioactivity: A new biomaterial for antiosteoporotic applications? Chem. Mater. 2008, 20, 4969-4973. [CrossRef]

111. Özarslan, A.C.; Yücel, S. Fabrication and characterization of strontium incorporated 3-D bioactive glass scaffolds for bone tissue from biosilica. Mater. Sci. Eng. C 2016, 68, 350-357. [CrossRef]

112. Hesaraki, S.; Gholami, M.; Vazehrad, S.; Shahrabi, S. The effect of Sr concentration on bioactivity and biocompatibility of sol-gel derived glasses based on CaO-SrO-SiO${ }_{2}-\mathrm{P}_{2} \mathrm{O}_{5}$ quaternary system. Mater. Sci. Eng. C 2010, 30, 383-390. [CrossRef] 
113. Zhang, Y.; Wei, L.; Chang, J.; Miron, R.J.; Shi, B.; Yi, S.; Wu, C. Strontium-incorporated mesoporous bioactive glass scaffolds stimulating in vitro proliferation and differentiation of bone marrow stromal cells and in vivo regeneration of osteoporotic bone defects. J. Mater. Chem. B 2013, 1, 5711-5722. [CrossRef]

114. Murphy, S.; Wren, A.W.; Towler, M.R.; Boyd, D. The effect of ionic dissolution products of Ca-Sr-Na-Zn-Si bioactive glass on in vitro cytocompatibility. J. Mater. Sci. Mater. Med. 2010, 21, 2827-2834. [CrossRef] [PubMed]

115. Grigoriadou, I.; Nianias, N.; Hoppe, A.; Terzopoulou, Z.; Bikiaris, D.; Will, J.; Hum, J.; Roether, J.A.; Detsch, R.; Boccaccini, A.R. Evaluation of silica-nanotubes and strontium hydroxyapatite nanorods as appropriate nanoadditives for poly(butylene succinate) biodegradable polyester for biomedical applications. Compos. Part B Eng. 2014, 60, 49-59. [CrossRef]

116. Koliakou, I.; Gounari, E.; Nerantzaki, M.; Pavlidou, E.; Bikiaris, D.; Kaloyianni, M.; Koliakos, G. Differentiation capacity of monocyte-derived multipotential cells on nanocomposite poly ( $\varepsilon$-caprolactone)-based thin films. Tissue Eng. Regen. Med. 2019, 16, 161-175. [CrossRef] [PubMed]

117. Kokubo, T.; Takadama, H. How useful is SBF in predicting in vivo bone bioactivity? Biomaterials 2006, 27, 2907-2915. [CrossRef] [PubMed]

118. Khambatta, F.B.; Warner, F.; Russell, T.; Stein, R.S. Small-angle X-ray and light scattering studies of the morphology of blends of poly (e-caprolactone) with poly(vinyl chloride). J. Polym. Sci. Pol. Phys. 1976. [CrossRef]

119. Tzetzis, D.; Tsongas, K.; Mansour, G. Determination of the mechanical properties of epoxy silica nanocomposites through FEA-supported evaluation of ball indentation test results. Mater. Res. 2017, 20, 1571-1578. [CrossRef]

120. Mansour, G.; Tzetzis, D.; Bouzakis, K.D. A nanomechanical approach on the measurement of the elastic properties of epoxy reinforced carbon nanotube nanocomposites. Tribol. Ind. 2013, 35, 190-199.

121. Tzetzis, D.; Mansour, G.; Tsiafis, I.; Pavlidou, E. Nanoindentation measurements of fumed silica epoxy reinforced nanocomposites. J. Reinf. Plast. Compos. 2013, 32, 160-173. [CrossRef]

122. Mansour, G.; Tzetzis, D. Nanomechanical characterization of hybrid multiwall carbon nanotube and fumed silica epoxy nanocomposites. Polym. Plast. Technol. Eng. 2013, 52, 1054-1062. [CrossRef]

Sample Availability: Samples of the compounds CaBG and SrBG are available from the authors.

(C) 2019 by the authors. Licensee MDPI, Basel, Switzerland. This article is an open access article distributed under the terms and conditions of the Creative Commons Attribution (CC BY) license (http://creativecommons.org/licenses/by/4.0/). 